\title{
Jakość tłumaczenia w serii translatorskiej - pieśń miłosna na sześć głosów
} Marta Kaźmierczak

\section{Założenia i cele}

Niniejszy artykuł stanowi próbę zbadania relacji zachodzących między pojęciami jakości i seryjności w tłumaczeniu literackim. Moim celem nie będzie wszakże ocena stopnia „doskonałości" tekstu docelowego na sposób normatywny, lecz raczej wymodelowanie ewentualnych regularności dających się zaobserwować w poetyce przekładu.

Pojęcie serii przekładowej zyskało w polskiej translatologii silną pozycję i duży wpływ, a metodologicznym punktem wyjścia stało się dlań uczynione przez Edwarda Balcerzana w 1968 roku spostrzeżenie, iż właśnie seria ,jest podstawowym sposobem istnienia przekładu artystycznego" ${ }^{1}$. Pojawienie się choćby jednego tłumaczenia danego utworu inicjuje serię, która zaczyna funkcjonować jako potencjalna. Jeśli mamy do czynienia z kilkoma przekładami, wówczas seria zostaje zrealizowana częściowo; częściowo - gdyż jest ona z natury nieskończona. Balcerzan kładzie zatem nacisk na rozwojowy charakter serii².

W zachodnich badaniach nad przekładem współistnienie różnych tłumaczeń jednego utworu zazwyczaj ujmuje się pod mianem retranslacji. O ile polskie pojmowanie seryjności przede wszystkim afirmuje wielość tekstów sekundarnych, to tradycję zachodnią zdominowała wysunięta przez Antoine Bermana tzw. hipoteza retranslacji, zakładająca nieuchronną porażkę tłumaczenia jako przesłankę kolejnych przybliżeń do oryginału ${ }^{3}$. Hipoteza ta wszelako przewiduje rów-

\footnotetext{
${ }^{1}$ E. Balcerzan, Poetyka przekładu artystycznego, [w:] tegoż, Literatura z literatury (Strategie tłumaczy), Katowice 1998, s. 18. Pierwodruk: „Nurt” 1968, nr 8.

2 Tamże. Wszystkie podkreślenia w artykule moje - M.K.

${ }^{3}$ A. Berman, La retraduction comme espace de la traduction, „Palimpsestes” 1990, t. 13, nr 4, s. 1-7.
} 
nież, iż każda następna wersja stara się być lepsza od poprzednich4 ${ }^{4}$ Ów „cel korekcyjny” wchodzi również w zakres Balcerzanowego rozumienia istoty przekładu, choć nie stanowi oczywiście jedynej funkcji tłumaczenia. Podobnie George Steiner postrzega następstwo alternatywnych wersji jako „akt wzajemnej kumulatywnej krytyki, pozwalającej poprawić tekst przekładu”.

Nie tylko idea rozwojowego charakteru serii translatorskiej, lecz również pewne wyrażenia w sposób oczywisty podsuwane przez dyskurs poniekąd wspierają domniemanie o rosnącej jakości tłumaczeń. Badacze skłonni są mówić raczej o rozwoju (co niesie z sobą sugestię doskonalenia) niż o przyroście serii, o degenerowaniu się nie wspominając. Podobnie marketingowe zastosowanie etykietki „nowy przekład” pokazuje, że uważa się, iż najnowsze ogniwo serii stanowi atrakcję $e^{6}$.

Tymczasem, jeżeli jakość w serii przekładowej miałaby się charakteryzować stałym wzrostem, musiałyby zostać spełnione następujące (nie zawsze osiągalne) warunki:

1. Tłumacze musieliby mieć świadomość istnienia poprzednich elementów serii.

Jak wykazuje Anna Legeżyńska w swoich badaniach nad wewnętrzną strukturą serii ${ }^{7}, \mathrm{czy}^{-}$ li statusem konkretnych przekładów w jej obrębie oraz ich wzajemnymi relacjami, sytuacja taka nie zawsze ma miejsce. Z jednej strony niektóre wcześniejsze tłumaczenia mogą ulegać marginalizacji (z różnych przyczyn) i nie stają się odniesieniem dla wersji późniejszych. Z drugiej strony niektóre dopełnienia serii mogą wprawdzie mieć charakter systemowy (i faktycznie wchodzić w dialog z elementami poprzedzającymi), inne jednak bywają okazjonalne i świadczą o braku wiedzy danego tłumacza o dokonaniach jego poprzedników lub też o braku zainteresowania nimi. Z kolei Marta Skwara zwraca uwagę, iż przekład może po prostu popaść w zapomnienie jeszcze przed ukazaniem się nowego tłumaczenia ${ }^{8}$.

2. Intencję tłumaczenia musiałoby stanowić przewyższenie przekładów istniejących.

Istotnie, poczucie nieadekwatności dotychczasowych wersji jest jedną z częstszych przyczyn ponawiania tłumaczeń. Nawet kiedy autor przekładu twierdzi, że chciał jedynie wydobyć inny aspekt danego dzieła, a zatem uzupełnić, nie zaś zanegować pracę innych, gdzieś w tle nadal czai się chęć rywalizacji, jak wyraziście sformułował to Stanisław Barańczak ${ }^{9}$, będący zresztą jednym z „głosów”, w które wsłuchamy się w empirycznej części niniejszego artykułu.

\footnotetext{
${ }^{4}$ Hipoteza ta spotkała się z zaskakująco bezkrytyczną akceptacją, zważywszy na zawarte w niej dość kontrowersyjne założenia, iż pierwsze czy wczesne przekłady są siłą rzeczy słabsze oraz że ich „słabość” tkwi w przyjmowaniu strategii „akulturacyjnej” zamiast „egzotyzującej”. Druga z tych tez została poddana krytyce m.in. w pracy: O. Paloposki, K. Koskinen, A Thousand and One Translations. Revisiting Retranslation, [w:] Claims, Changes and Challenges in Translation Studies. Selected Contributions From the EST Congress, Copenhagen 2001, red. H. Hyde, K. Malmkjær, D. Gile, Amsterdam 2004, s. 27-38. Próbę zmiany perspektywy podjęła natomiast F. MassardierKenney w artykule Toward a Rethinking of Retranslation, „Translation Review” 2015, t. 92, nr 1, s. 73-85.

${ }^{5}$ G. Steiner, Po wieży Babel. Problemy języka i przekładu, przeł. O. i W. Kubińscy, Kraków 2000, s. 558.

${ }^{6}$ Głosy negatywnie oceniające seryjność tłumaczeń odzywają się niezwykle rzadko. W przypadku Małgorzaty Łukasiewicz wydaje się, że tłumaczka po prostu daje się ponieść retorycznej swadzie obrony star(sz)ych przekładów i dlatego odrzuca skojarzenia z „nowymi szatami” oraz „seryjną produkcją” (M. Łukasiewicz, Pięć razy o przekładzie, Kraków-Gdańsk 2017, s. 83-84).

${ }^{7}$ A. Legeżyńska, Struktura serii, [w:] tejże, Tłumacz i jego kompetencje autorskie, wyd. 2, Warszawa 1999, s. 192-196.

${ }^{8}$ M. Skwara, Polskie serie recepcyjne wierszy Walta Whitmana. Monografia wraz z antologiq przekładów, Kraków 2014, s. 17, 79-91.

${ }^{9}$ S. Barańczak, Maty lecz maksymalistyczny manifest translatologiczny, „Teksty Drugie” 1990, nr 3, s. 7-8.
} 
Nowe przekłady powstają jednak z najróżniejszych powodów, często w oderwaniu od kwestii jakości, za to w powiązaniu z czynnikami ekonomicznymi, ideologicznymi bądź z prawem autorskim. Wskażmy kilka przykładów:

- Wydawca może zamówić nowe tłumaczenie po kosztach niższych od wysokości tantiem za istniejący przekład, co nie sprzyja wysokiej jakości nowych ogniw serii (tego rodzaju konsekwencje polskiego prawa autorskiego analizowała Anna $\mathrm{Moc}^{10}$ ).

- Józef Zarek przywołuje przypadek wydanego w latach osiemdziesiątych w drugim obiegu zbioru wierszy Jaroslava Seiferta, w którym przekłady (nowe) podpisano pseudonimami; nie można było przedrukować tłumaczeń wcześniejszych, gdyż prowadziłoby to do ujawnienia tożsamości ich autorów ${ }^{11}$.

- Ponowienie przekładu może wiązać się z określonymi wymogami politycznymi i mieć patronat ideologiczny, co trafnie ilustruje przypadek niemieckich tłumaczeń klasycznej powieści fińskiej analizowany przez Pekkę Kujamäkiego ${ }^{12}$. W takich sytuacjach nowe przekłady wyrastają z potrzeby nadążania za okolicznościami społeczno-historycznymi, a nie z poszukiwań artystycznego optimum.

- W ostatnich dekadach teatry brytyjskie podsycały modę na liczne „nowe wersje” sztuk z repertuaru światowej klasyki, angażując do ich tworzenia wziętych dramatopisarzy, których nazwiska miały przyciągnąć widownię; ów trend opisała Helen Rappaport, należąca do grona marginalizowanych ekspertów językowych zatrudnianych do „pomocy przy pracy z oryginałem” ${ }^{13}$.

3. Tłumacze musieliby być zaznajomieni z aktualnym stanem badań nad twórczością danego autora lub nad danym dziełem, a także z krytyką przekładów dokonanych przez ich poprzedników. I znów, jak pokazuje praktyka, autorzy tłumaczeń nie zawsze podejmują takie studia przygotowawcze, a w przypadku zwłaszcza poezji wysiłek translatorski bywa podejmowany z czystej fascynacji estetycznej oryginałem. Dobrym przykładem może tu być antologia angielskich przekładów szkolnego kanonu poezji polskiej dokonanych przez Jarka Zawadzkiego ${ }^{14}$, co żadną miarą nie dyskredytuje jego pracy.

4. Tłumacze musieliby mieć swobodę wykorzystywania najbardziej fortunnych rozwiązań poprzedników.

Owszem, Anna Legeżyńska stwierdza, że w dziedzinie przekładu „postęp jest, by tak rzec, kolektywny i reguła plagiatu na poziomie niższych układów stylistycznych nie działa"15. Jednak praktyka zdaje się wskazywać na coś przeciwnego: tłumacze unikają powtarzania chwytów i sformułowań zastosowanych przez kogoś innego, a jeśli je powielają, to zwykle są za to kry-

\footnotetext{
${ }^{10} \mathrm{~A}$. Moc, Nowe polskie prawo autorskie a kolejne tłumaczenia na naszym rynku wydawniczym, czyli przygody Pinoccia lub Pinokio, [w:] Między oryginałem a przekładem, t. III: Czy zawód tłumacza jest w pogardzie?, red. M. FilipowiczRudek, J. Konieczna-Twardzikowa, M. Stoch, Kraków 1997, s. 181-183.

${ }^{11}$ J. Zarek, Seria jako zbiór tłumaczeń, [w:] Przekład artystyczny, vol. 2: Zagadnienia serii translatorskich, red. P. Fast, Katowice 1991, s. 10.

${ }^{12}$ P. Kujamäki, Finnish Comet in German Skies. Translation, Retranslation and Norms, „Target” 2002, t. 13, nr 1, s. 45-70.

${ }^{13} \mathrm{H}$. Rappaport, Chekhov in the Theatre: The Role of the Translator in New Versions, [w:] Voices in Translation, red. G. Anderman, Clevedon-Buffalo-Toronto 2007, s. 66-77, zwł. s. 68 i 74.

${ }^{14}$ Selected Masterpieces of Polish Poetry, tłum. z polskiego Jarek Zawadzki, [Charleston S.C.] 2007.

${ }^{15}$ A. Legeżyńska, Struktura serii, s. 195. Pogląd ten powtarza Dorota Urbanek: zob. D. Urbanek, The Translators' Adventures in „Alice's Wonderland”, [w:] Translation and Meaning, cz. 6, red. M. Thelen, B. LewandowskaTomaszczyk, Łódź-Maastricht 2002, s. 473.
} 
tykowani ${ }^{16}$. Co więcej, jak przekonująco wykazał Grzegorz Ojcewicz, bariera plagiatu może ograniczać rozwój serii. W przypadku krótkiego wiersza, twierdzi badacz, kolejne przekłady stopniowo wyczerpują możliwe rozwiązania lokalne i doprowadzają serię do jej granic ${ }^{17}$. W sumie, jak głosi słynne ${ }^{18}$ powiedzenie Balcerzana, nie należy „ulega[ć] złudzeniu, że ten przekłada najlepiej, kto przekłada ostatni" ${ }^{\prime 19}$. Dorota Urbanek zauważa, iż na wydłużanie serii mogą wpływać różne czynniki wewnętrzne i zewnętrzne ${ }^{20}$. W efekcie jakość w obrębie serii faktycznie istniejących, jeśliby ją przedstawiać w formie wykresu, rzadko przybierałaby postać krzywej wznoszącej się równomiernie.

Jak zatem może wyglądać taki wykres? Spróbuję zbadać tę kwestię na przykładzie polskich tłumaczeń The Love Song of J. Alfred Prufrock (Pieśni miłosnej J. Alfreda Prufrocka) T.S. Eliota. Po pierwsze, wybierając do analizy kanoniczny utwór współczesny, w dodatku taki, którym zajęli się znamienici tłumacze, mam nadzieję zaobserwować jako przyczynę retranslacji faktyczne dążenie do doskonalenia przekładu - jeśli takowe miało miejsce - a nie tylko potrzebę jego językowego uaktualnienia wynikającą z upływu czasu. Po drugie, choć w pewnym okresie poezja Eliota była w Polsce odrzucana z powodów ideologicznych (jak stwierdził jeden z tłumaczy, „[p]rzełom lat czterdziestych był u nas prawdziwym czyśćcem Eliota”21), omawiane przekłady powstały później i nic nie wskazuje na to, by którykolwiek z nich służył wymogom politycznym chwili. Można zatem oczekiwać, że rezultaty analizy będą wynikać jedynie z poetyki dzieł(a).

\section{Podejście przyjęte w pracy}

Zjawisko serii przekładowej stanowi przedmiot zarówno refleksji teoretycznej, jak i badań empirycznych ${ }^{22}$. Jak wylicza Skwara, można je wykorzystywać jako materiał oraz metodę do ustalania hierarchii istniejących tłumaczeń, a także do analizowania różnych poetyk, języka artystycznego i dykcji charakterystycznych dla poszczególnych epok lub pisarzy, do badania rozmaitych interpretacji jednego tekstu zawartych w jego przekładach, do zgłębiania różnic językowych oraz kulturowych ${ }^{23}$. Przede wszystkim jednak badaczka trafnie określa metodologiczne ograniczenia tego pojęcia, wskazując na konstruktowy, niejako sztuczny charakter serii i na niebezpieczeństwo izolowania przekładów ze społeczno-historycznych kontekstów kultury docelowej ${ }^{24}$.

Przekład poetycki to dziedzina, w obrębie której z jednej strony seryjność staje się najbardziej widoczna, z drugiej zaś - ocena jakości jest szczególnie problematyczna i najczęściej uznawana

\footnotetext{
${ }^{16}$ Zob. np. negatywne reakcje (na gruncie estetycznym, jak i etycznym) na dokonany przez Marię Leśniewską eksperymentalny „kolażowy” przekład wiersza Baudelaire’a Podróż (oryg. Le Voyage): Z. Bieńkowski, W sprawie Baudelaire’a i J. Waczków, Ryzyko, „Literatura na Świecie” 1985, nr 3 (164), s. 354-364.

${ }^{17} \mathrm{G}$. Ojcewicz, Granice serii, [w:] tegoż, Epitet jako cecha idiolektu pisarza, Katowice 2002, s. 375-404.

${ }^{18}$ Zob. M. Skwara, Wyobraźnia badacza - od serii przekładowej do serii recepcyjnej, „Poznańskie Studia Polonistyczne. Seria Literacka" 2014, nr 23 (43), s. 107.

${ }^{19} \mathrm{E}$. Balcerzan, Tajemnica istnienia (sporadycznego) krytyki przekładu, [w:] Krytyka przekładu w systemie wiedzy o literaturze, red. P. Fast, Katowice 1999, s. 34.

${ }^{20}$ D. Urbanek, The Translators' Adventures..., s. 472.

${ }^{21}$ M. Sprusiński, Poeta wielkiego czasu, [w:] T.S. Eliot, Poezje, red. i posłowie M. Sprusiński, Kraków 1978, s. 229.

${ }^{22}$ Wczesnym przykładem zainteresowania tym zagadnieniem w Polsce jest tom pokonferencyjny Przekład artystyczny t. 2: Zagadnienia serii translatorskich, red. P. Fast, Katowice 1991. Bardziej szczegółowy przegląd teorii i badań związanych z serią przekładową zawiera książka Agnieszki Adamowicz-Pośpiech poświęcona analizie polskich retranslacji wybranych utworów Josepha Conrada (A. Adamowicz-Pośpiech, Seria w przekładzie. Polskie warianty prozy Josepha Conrada, Katowice 2013).

${ }^{23} \mathrm{M}$. Skwara, Polskie serie recepcyjne..., s. 11.

${ }^{24} \mathrm{M}$. Skwara, Polskie serie recepcyjne..., s. 11, 16.
} 
za subiektywną. Pewną obiektywność w tym względzie może zapewnić, jak się wydaje, przyjęcie za punkt wyjścia poetyki tekstu - z takiego przekonania wyrastają koncepcje przekładowych dominant, by wymienić dominantę semantyczną Stanisława Barańczaka ${ }^{25}$ czy zaproponowaną w odpowiedzi na nią przez Annę Bednarczyk dominantę translatorską ${ }^{26}$. Koncepty te legitymują się sprawdzoną przydatnością metodologiczną, zwłaszcza jeżeli - jak argumentowałam przy innej okazji ${ }^{27}$ - zagwarantujemy intersubiektywny charakter takiego narzędzia krytycznego.

Jednak na ogół nie sposób sprowadzić poetyki utworu do jednego kluczowego elementu, stąd też brak metodologicznej stabilności w krytyce przekładu. Stwierdziwszy, że nie istnieje żadna ustalona metoda analizowania serii przekładowej, Dorota Urbanek zaproponowała pewną elementarną procedurę $e^{28}$. Z kolei Lance Hewson w swoim książkowym studium ${ }^{29} \mathrm{kładzie}$ nacisk na potrzebę, z jednej strony, ograniczenia impresyjności krytyki, z drugiej zaś - mierzenia efektów interpretacyjnych (porównywania potencjałów interpretacyjnych oryginału i przekładu). W odniesieniu do badanego przez siebie materiału powieściowego proponuje, by czynić to w sposób sformalizowany, licząc poszczególne transformacje (czy raczej ich skutki) w wybranych segmentach tekstu i odnosząc wynik do całości celem oszacowania proporcji przesunięć, co pozwala ocenić skalę i efekty interpretacyjne zmian. Wydaje się, że warto podjąć próbę podobnej obiektywizacji na gruncie krytyki przekładu poetyckiego.

W niniejszym studium badaniu poddane zostaną cztery obszary istotne dla poetyki oryginalnego utworu jako całości: muzyczność Eliotowskiego wiersza, motyw niezdecydowania traktowany jako tematyczny rdzeń Pieśni miłosnej J. Alfreda Prufrocka, dykcja poetycka oraz wymiar intertekstualny. W obrębie każdego z tych zagadnień rozpatrzone zostaną mniejsze zespoły elementów bądź aspekty tekstu źródłowego, których zachowanie lub utratę w przekładzie można wykazać w sposób bardziej uchwytny. Chodzić mi będzie nie tyle o zweryfikowanie efektywności poszczególnych rozwiązań translatorskich, co o zarejestrowanie fluktuacji lub wzrostu jakości w danym aspekcie poetyki utworu. Zestawienie wyników w poszczególnych sferach złoży się na wypadkową, która pozwoli określić ogólny stopień adekwatności tłumaczenia w konkretnym momencie rozwoju serii. Celem analizy nie jest pokazanie, jak wczesny poemat Eliota był interpretowany przez kolejnych polskich tłumaczy, ale raczej zweryfikowanie pewnych założeń dotyczących serii przekładowej jako takiej. $Z$ tego względu rozpatruję jedynie wybrane cechy utworu, a w niektórych punktach przedstawiam rezultaty analizy, bez przytaczania jej przebiegu.

\section{Polscy Prufrockowie}

The Love Song of J. Alfred Prufrock ${ }^{30}$, utwór, który, jak się uznaje, dał początek poetyce modernizmu, powstał w roku 1911 i ukazał się w pierwszym zbiorze wierszy T.S. Eliota zatytułowanym Prufrock and Other Observations, wydanym w roku 1917. Polską recepcję twórczości Eliota ot-

${ }^{25}$ S. Barańczak, Mały lecz maksymalistyczny manifest translatologiczny, s. 36.

${ }^{26}$ A. Bednarczyk, W poszukiwaniu dominanty translatorskiej, Warszawa 2008, s. 13; tejże, Wybory translatorskie, Łódź 1999, s. 19.

${ }^{27}$ M. Kaźmierczak, Jak wyglq̨da koniec świata? Dominanty w przekładach wiersza Czesława Miłosza, „Między Oryginałem a Przekładem” 2012, t. 18: Dominanta a przekład, red. A. Bednarczyk, J. Brzozowski, s. 112-113.

${ }^{28}$ D. Urbanek, The Translators' Adventures in „Alice's Wonderland," s. 473.

${ }^{29}$ L. Hewson, An Approach to Translation Criticism. „Emma” and „Madame Bovary” in Translation, Amsterdam 2011.

${ }^{30}$ T.S. Eliot, The Love Song of J. Alfred Prufrock, [w:] T.S. Eliot, Wybór poezji, red. K. Boczkowski, W. Rulewicz, wstęp W. Rulewicz, Wrocław 1990, s. 3-9. Kolejne cytaty pochodzą z tego wydania. 
wiera pięć przekładów jego „wierszy (wśród których nie było Prufrocka) opublikowanych w czasopismach przez Józefa Czechowicza w latach trzydziestych XX wieku ${ }^{31}$. Druga wojna światowa uniemożliwiła jakiekolwiek szersze oddziaływanie kultury anglosaskiej na kulturę polską, później zaś epoka stalinizmu postawiła bariery ideologiczne recepcji poety tak wysoce intelektualnego, religijnego, hermetycznego i konserwatywnego. Garść wierszy ukazała się w czasopismach literackich, łącznie z tłumaczeniem The Love Song z 1948 roku autorstwa Władysława Dulęby ${ }^{32}$, jednak utwór ten zyskał większy rezonans dopiero po przedrukowaniu go w pierwszym polskim wyborze wierszy Eliota z roku $1960^{33}$. Następny przekład, dokonany przez Michała Sprusińskiego, pochodzi z roku 1978 i ukazał się w tomie złożonym z zupełnie nowych tekstów ${ }^{34}$. Do lat dziewięćdziesiątych ubiegłego wieku tłumaczenia te pozostawały jedynymi wersjami Prufrocka dostępnymi po polsku - przynajmniej w sensie praktycznym ${ }^{35}$. Kolejne trzy przekłady ukazały się w ciągu dekady i można je traktować jako synchroniczny odcinek serii. Adam Pomorski opublikował swoją propozycję w roku 1993, a następnie włączył jako pierwszy utwór do własnego reprezentatywnego wyboru poezji Eliota ${ }^{36}$. Przekład Stanisława Barańczaka pochodzi z roku $1998^{37}$. Najnowsza jest wersja Krzysztofa Boczkowskiego (2001), który powraca do poezji Eliota nieustannie od lat czterdziestu. Tekst ten został przedrukowany w latach $2013^{38}$ i 2016, zatem pozostaje jak dotąd „ostatnim słowem”, także z perspektywy obecności w czytelniczym obiegu.

\section{Walory fonoestetyczne}

W The Love Song of J. Alfred Prufrock następstwo obrazów i myśli organizuje rytm, a uwagę zwracają też liczne korespondencje dźwiękowe, dlatego wydaje się stosownym rozpocząć nasz przegląd od jakości fonoestetycznych. Marjorie Perloff twierdzi, że w poemacie Eliota to właśnie brzmienie stanowiło cechę najbardziej frapującą dla czytelnika w roku 1917 i pozostaje nią nadal ${ }^{39}$. Badaczka wskazuje subtelne asonanse i echa w pierwszych wersach utworu i dowodzi,

${ }^{31}$ Zob. J. Czechowicz, Poezje zebrane, red. A. Madyda, Toruń 1997, s. 478-484.

${ }^{32}$ T.S. Eliot, Pieśń miłosna J. Alfreda Prufrocka, przeł. W. Dulęba, [w:] tegoż, Wybór poezji, s. 9-14. Pierwodruk: „Znak” 1948, nr 7. Kolejne cytaty pochodzą z wydania z 1990 roku.

${ }^{33}$ T.S. Eliot, Poezje wybrane, wstęp W. Borowy, Warszawa 1960. Prufrock na stronach 43-51.

${ }^{34}$ T.S. Eliot, Pieśń miłosna J. Alfreda Prufrocka, przeł. M. Sprusiński, [w:] tegoż, Poezje, red. i posłowie M. Sprusiński, Kraków 1978, s. 7-13. Kolejne cytaty z tego wydania.

${ }^{35}$ Istnieje bowiem wersja współczesna przekładowi Sprusińskiego, autorstwa Jerzego Niemojowskiego, opublikowana wraz z esejem o Eliocie i sztuce przekładu w Londynie w ograniczonym nakładzie (Miłosna Pieśń [sic] J. Alfreda Prufrocka, przeł. J. Niemojowski, [w:] T.S. Eliot, Dziewięć poematów. Przekład i szkic o teorii i praktyce przekładu poetyckiego, „Syrinx” 1978, nr 1, Sumptibus privatis Londini, s. 51-54). Publikację wydrukowano do „rozpowszechniania ograniczonego” i zastrzeżono jej przedruk (zob. strona redakcyjna), pozostawała zatem niedostępna dla szerszych kręgów czytelniczych w Polsce. Świadoma wagi zastrzeżeń Skwary co do „konstrukcyjnego” charakteru serii, którą wydobywa z tła i porządkuje oko badacza, zamierzam obrócić ten fakt na swoją korzyść i wyłączyć przekład Niemojowskiego z moich analiz, jako że z perspektywy zainteresowanego, lecz nieprofesjonalnego czytelnika polskiego najprawdopodobniej nie wpisywał się on w poszukiwania tłumaczeniowej optymalności.

${ }^{36}$ T.S. Eliot, Śpiew miłosny J. Alfreda Prufrocka, przeł. A. Pomorski, [w:] tegoż, W moim początku jest mój kres, tłum. i red. A. Pomorski, Warszawa 2007. Pierwodruk: „Twórczośc” 1993, nr 1, s. 3-6. Kolejne cytaty z edycji książkowej z 2007 roku.

${ }^{37}$ T.S. Eliot, Pieśn miłosna J. Alfreda Prufrocka, przeł. S. Barańczak, [w:] Od Walta Whitmana do Boba Dylana. Antologia poezji amerykańskiej, przeł. S. Barańczak, Kraków 1998, s. 110-115. Kolejne cytaty z tego wydania.

${ }^{38}$ T.S. Eliot, Pieśń miłosna J. Alfreda Prufrocka, przeł. K. Boczkowski, [w:] tegoż, Szepty nieśmiertelności, przeł. K. Boczkowski (2001), wyd. V, Toruń 2013, s. 96-100. Kolejne cytaty z tego wydania. Tekst przekładu oraz komentarzy porównano z wydaniem VI z roku 2016 (s. 95-99 oraz 99-102), nazwanym przez tłumacza „ostatecznym” - przynosi ono drobne zmiany leksykalne i interpunkcyjne (nie zawsze na lepsze), które nie obejmują materiału cytowanego w artykule i nie wpływają na formułowane tu oceny.

${ }^{39}$ M. Perloff, Awangardowy Eliot, przeł. T. Cieślak-Sokołowski, „Czytanie Literatury. Łódzkie Studia Literaturoznawcze" 2012, nr 1, s. 284. 
iż są one efektem świadomego, starannego doboru słów ${ }^{40}$. Joan Fillmore Hooker podkreśla natomiast w kontekście przekładu, że odtworzenie brzmienia i rytmu to warunek sine qua non uzyskania ekwiwalencji wobec Eliotowskiego oryginału ${ }^{41}$.

Dwa najwcześniejsze polskie przekłady nie wypadają pod tym względem najlepiej: choć można w nich znaleźć fragmenty zrytmizowane, niektóre dłuższe odcinki tekstu nie wykazują żadnego rytmu. Jest to wyraźne zwłaszcza w tłumaczeniu Władysława Dulęby, co potwierdza obserwacje poczynione przez Magdalenę Heydel w odniesieniu do jego przekładu Gerontiona $a^{42}$. Michał Sprusiński od czasu do czasu wprowadza uchwytne pulsacje, ale występują one obok fragmentów brzmiących płasko i bardzo zbliżonych do prozy. Wersy, które będę przytaczać w dalszej części artykułu, często dowodzą, że tłumacze nie przywiązywali wystarczająco dużej wagi do organizacji rytmicznej poematu.

Inaczej niż oryginał, który rozbrzmiewa echami, aliteracjami i rymami wewnętrznymi, pierwsze dwa polskie przekłady wykorzystują te środki tylko incydentalnie. Rymy są przeważnie niedokładne lub przybliżone i zostają odtworzone w pierwszych dwóch strofach oraz w dwuwierszu o Michale Aniele, a później pojawiają się sporadycznie. Zarówno Dulęba, jak i Sprusiński najwyraźniej nie zdawali sobie sprawy z fundamentalnego znaczenia jakości muzycznych w poemacie Eliota. Jak słusznie zauważa Heydel ${ }^{43}$, niektóre wady wczesnych polskich tłumaczeń Eliota wypada łączyć z brakiem dostępu do szerszych, żywych kontekstów anglojęzycznej poezji dwudziestowiecznej, spowodowanym istnieniem żelaznej kurtyny. Niezrozumienie roli dźwiękowej organizacji poematu może należeć do tej kategorii.

Przekłady późniejsze są znacznie bardziej umuzycznione. Adam Pomorski po mistrzowsku odtwarza dźwiękową strukturę The Love Song z jej rozpoznawalnymi rytmami, licznymi rymami i sporadycznym echem wewnętrznym. Niekiedy nawet wzmacnia schemat rymowy, co można uznać za gest kompensacyjny, jako że w poezji polskiej rymy są (lub były) i ważniejsze, i bardziej wyraziste niż w tradycji anglosaskiej. Pod względem brzmienia Śpiew miłosny J. Alfreda Prufrocka potwierdza opinię Jean Ward, że dokonywane przez Pomorskiego przekłady z Eliota są nienaganne, jeśli chodzi o jakości rytmiczne ${ }^{44}$. Uznawany za mistrza formy Stanisław Barańczak, który słynie ze swych nieomal karkołomnych wyczynów wersyfikacyjnych w przekładach poezji, tu również okazuje się bardzo wyczulony na muzyczność. Buduje on strukturę rymów i ech wewnętrznych, nie wzmacniając jednak owej cechy poematu Eliota. Obaj tłumacze wprowadzają też pewne korespondencje dźwiękowe porównywalne z eufonią oryginału. Co istotne, udaje im się osiągnąć ekwiwalencję foniczną bez wpadania w pułapkę, o której wspomina Umberto Eco: przesłodzenia tego, co miało brzmieć cierpko ${ }^{45}$. Krzysztof Boczkowski jest w pełni świadomy subtelności Eliotowskiej wersyfikacji, o czym świadczy komentarz zwracający uwagę czytelni-

\footnotetext{
${ }^{40}$ Tamże, s. 284-286.

${ }^{41}$ J.F. Hooker, „La Chanson d'amour de J. Alfred Prufrock” (Sylvia Beach an Adrienne Monier, Pierre Leyris, Marice Le Breton), [w:] T.S. Eliot's Poems in French Translation: Pierre Leyris and Others, Ann Arbor [in England: Epping] 1983, s. 45, 57.

${ }^{42}$ M. Heydel, Obecność T.S. Eliota w literaturze polskiej, Wrocław 2002, s. 154-155.

${ }^{43}$ Tamże, s. 155-156.

${ }^{44} \mathrm{~J}$. Ward, Kilka luźnych uwag na temat najnowszego przekładu poezji Eliota, „Przekładaniec” 2008, nr 21, s. 226.

${ }^{45}$ U. Eco, Dire quasi la stessa cosa. Esperienze di traduzione, Milano 2004, s. 274. Eco omawia wybrane zagadnienia włoskich i francuskich przekładów Prufrocka na s. 270-275.
} 
ków na jedyny segment utworu, w którym poeta całkowicie zrezygnował z rymów ${ }^{46}$. Najnowszy przekład zawiera zatem rymy, jest również zorganizowany rytmicznie, choć nie tak kunsztownie jak tłumaczenia Pomorskiego czy Barańczaka. Co więcej, niektóre rozwiązania Boczkowskiego bywają banalne (i to nie wtedy, gdy Eliot celowo odwołuje się do kiczu), np. w zakończeniu poematu, gdzie mowa o śpiewie syren, dwukrotnie pojawia się oklepana para rymowa $w$ dal - fal.

Wzorce brzmieniowe poszczególnych tekstów dobrze ilustruje strofa obejmująca wersy 99110 (od słów „And would it have been worth it, after all, / Would it have been worth while”). Tam, gdzie Eliot stawia raczej na słowne powtórzenia niż rym właściwy, Pomorski proponuje bogaty schemat współbrzmień, wzmocniony dodatkowo rymem wewnętrznym (,To nie to, o co mi szło", w. 109) i tylko jeden wers pozostaje u niego niezrymowany (w. 107, E):

$\begin{array}{ll}\text { I cóż by koniec końców z tego przyszło nam, } & \text { A } \\ \text { Cóż z tego w rzeczy samej, } & \text { B } \\ \text { Z zachodów słońca i z podwórek, i z wodą spłukiwanych bram, } & \text { A } \\ \text { Z powieści i z herbaty, i z sukien w powłóczystym stylu - } & \mathrm{C} \\ \text { Z tego i jeszcze z rzeczy tylu? } & \mathrm{C} \\ \text { Rozum wszystkiego nie ogarnia! } & \mathrm{D} \\ \text { Jeżeli nawet schemat nerwów rzuci na ekran latarnia: } & \mathrm{D} \\ \text { Cóż nam z tego w rzeczy samej, } & \mathrm{B}= \\ \text { Skoro moszcząc poduszkę czy zrzucając szal, } & \mathrm{E} \text { (ason. z A) } \\ \text { Zwrócona w stronę okna, powie, kręcąc głową: } & \mathrm{F} \\ \text { „o nie to, o co mi szło, } & \mathrm{g}-\mathrm{g} \\ \text { Nie to, daję słowo” (Pomorski, w. 99-110). } & \mathrm{F}\end{array}$

W tym samym segmencie poematu Barańczak używa dwóch rymów pełnych, dwóch tautologicznych i pozostawia trzy klauzule wersowe bez rymów, Boczkowski zaś tylko raz sięga po rym tautologiczny, uzyskując w sumie trzy rymy. Dulęba i Sprusiński stosują w tej strofie po dwie, identyczne u obu, pary rymów: ulicach - spódnicach i szale - wcale, co jest rozwiązaniem podsuwanym przez leksykę oryginału („streets”, „skirts”, „shawl”, „at all”).

Zważywszy na nieregularne rozmieszczenie współbrzmień w poemacie Eliota, w tłumaczeniach można je bez trudu odtwarzać w różnych miejscach. Jednak w przypadku dwuwiersza "In the room the women come and go / talking of Michelangelo" (ww. 13-14, 35-36) wydaje się istotne zachowanie formy celowo niezgrabnej, częstochowskiej rymowanki. Dulębie, Sprusińskiemu i Pomorskiemu udało się powtórzyć w klauzuli imię artysty i znaleźć dlań naturalnie brzmiącą parę. Pierwszy z nich utrzymał perypatetyczny charakter rozmowy („W salonie, gdzie kobiet przechadza się wiele"), natomiast Pomorski osiągnął maksymalną swobodę frazy w języku docelowym: „Panie w salonie rozprawiają wiele / O Michale Aniele”. Barańczak posłużył się mocnym asonansem, inaczej segmentując frazę i dzieląc ją na trzy zdaniowe równoważniki:

W salonie - panie, pań, paniami, paniom.

Konwersacja. Temat: Michał Anioł (Barańczak, w. 13-14).

${ }^{46}$ T.S. Eliot, Szepty nieśmiertelności, komentarz tłumacza na s. 102. 
Powtórzenie rzeczownika panie w różnych przypadkach tworzy skróconą i przetasowaną deklinację, co w języku polskim sugeruje nawracanie tematu. W ten sposób kobiety same stają się przedmiotem rozmowy, określonej tu pochodzącym z łaciny słowem konwersacja. Dwuwiersz zachowuje ironiczną wymowę skierowaną pod adresem salonowej elegancji, ale jego forma staje się znacznie bardziej wyszukana. W istocie wersja Barańczaka brzmi najzjadliwiej, co można uznać za zaletę, jeśli się weźmie pod uwagę ironię wpisaną w oryginalny rym

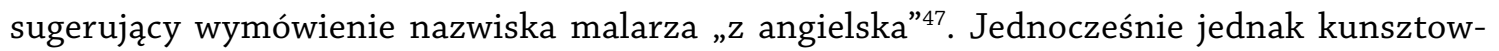
ność jest cechą niekoniecznie pożądaną w wersach, które mają implikować błahość rozmowy $^{48}$. Jeśli idzie o przekład Boczkowskiego, znajdujemy w nim niklejsze echo: panie - Anioł. Zarówno to rozwiązanie, jak i Barańczakowe mogło być motywowane chęcią niepowtarzania tego, co zaproponowali poprzednicy.

Zaobserwowane powyżej cechy tłumaczeń można podsumować w formie tabeli ukazującej translatorskie wybory w zarytmetyzowanej formie. Jeśli następnie przetransponujemy wyniki na wykres, zilustrują nam one fluktuacje w obrębie tego jednego aspektu poetyki utworu w polskiej serii przekładowej. Muzyczność głosu Eliota osiąga najwyższy poziom w tłumaczeniu trzecim i czwartym.

Tabela 1. Odtworzenie muzycznych walorów wiersza w poszczególnych przekładach

\begin{tabular}{|c|c|c|c|c|c|}
\hline \multirow{2}{*}{ Składniki } & \multicolumn{5}{|c|}{ Tłumacz } \\
\hline & Dulęba & Spusiński & Pomorski & Barańczak & Boczkowski \\
\hline rytm (x2) & - & - & ++ & ++ & + \\
\hline rymy & 0,5 & 0,5 & + & + & 0,5 \\
\hline dwuwiersz 'MA' & + & + & + & $\begin{array}{c}0,5 \\
\text { (wyrafinowanie) }\end{array}$ & $\begin{array}{c}- \\
\text { (brak rymu) }\end{array}$ \\
\hline $\begin{array}{c}\text { efekty } \\
\text { dźwiękowe }\end{array}$ & - & - & + & + & 0,5 \\
\hline Wynik:_/10 & 3 & 3 & 10 & 9 & 4 \\
\hline
\end{tabular}

We wszystkich częściach analizy wynik został skalkulowany względem przelicznika „10”, co pozwoli rzutować zsumowane rezultaty cząstkowe na wspólny wykres w tej samej skali. + oznacza w pełeni udane odtworzenie tekstu źródłowego

(x2) - element kluczowy liczony podwójnie

${ }^{47}$ Zob. U. Eco, Dire quasi la stessa cosa..., s. 270.

${ }^{48}$ Tę kwestię podjęto w dyskursie krytycznym w kontekście zastąpienia Michała Anioła „mistrzami ze Sieny” we francuskim przekładzie poematu Eliota dokonanym przez Pierre’a Leyrisa. Jak zauważył Umberto Eco, wzmianka o sieneńskiej szkole malarstwa wymaga jednak pewnej orientacji w historii sztuki, podczas gdy nawiązanie do Michała Anioła może pozostawać najzupełniej powierzchowne (U. Eco, Dire quasi la stessa cosa..., s. 271; zob. też J.F. Hooker, T.S. Eliot’s Poems in French..., s. 52, na temat odbioru propozycji Leyrisa). 


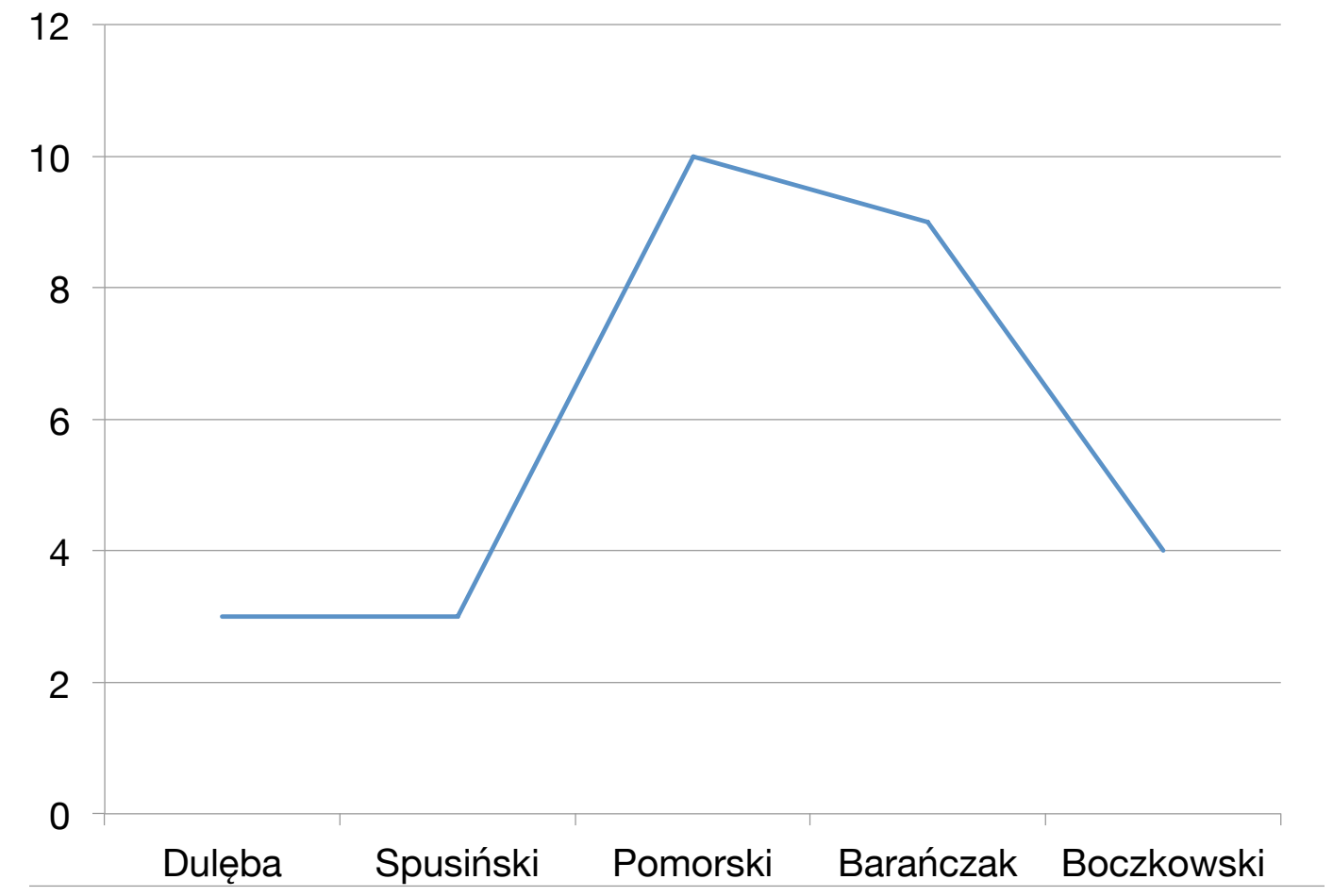

Wykres 1. Walory dźwiękowe w badanej serii

\section{Rdzeń tematyczny: niepewność i niezdecydowanie}

Większość badaczy i odbiorców przekładów przypuszczalnie zgodziłaby się, iż tematyczny rdzeń danego tekstu stanowi nieodzowny składnik inwariantu wszystkich jego tłumaczeń oraz czynnik wpływający na ich jakość. W przypadku The Love Song tym, co konstytuuje tematyczną oś poematu, są niepewność i niezdecydowanie, przejawiana przez Prufrocka niechęć (czy też niezdolność) do zadania „the overwhelming question” - „przytłaczającego pytania” z ww. 10 i 93. Temat ten przenika również do poetyki tego monologu dramatycznego, gdyż sam sposób wypowiadania na różne sposoby komunikuje i ujawnia kłopotliwe położenie podmiotu wiersza. Wybrane fragmenty utworu posłużą do zbadania, jak z tą kwestią radzą sobie tłumacze.

Niepewność, „zamierzony temat” całego tomu poetyckiego z $1917 \mathrm{roku}^{49}$, wysuwa się na plan pierwszy już w słynnej początkowej strofie otwierającego ów tom poematu. Niestabilność „ja” mówiącego ujawnia tu rozdwojenie na „ty i ja”. Owo dédoublement persony, w manierze Laforgue'a, autoironicznie wyraża zmaganie się podmiotu z samym sobą ${ }^{50}$. Wszystkie przekłady zachowują owo inicjalne rozszczepienie, lecz późniejsze odwołania do „ty” przysparzały tłumaczom nieco trudności. W tej samej strofie Dulęba, pisząc o zamysłach „[d]oprowadzania ciebie do tych ciągłych pytań" (w. 10), niepotrzebnie stosuje emfatyczny biernik - zamiast krótkiego cię - co sugeruje, że owo „ty” jest istotnie drugą postacią ${ }^{51}$. Dalej tłumacz wstawia zaimek osobowy tam, gdzie w tekście polskim powinien zostać opuszczony:

${ }^{49}$ Por. J.X. Cooper, The Cambridge Introduction to T.S. Eliot, Cambridge 2006, s. 44.

${ }^{50}$ Por. T.S. Eliot, A Commentary, „The Criterion” 1933, t. XII, nr 48, s. 469.

${ }^{51}$ Wśród badaczy nie ma zgody co do tego, czy w utworze występuje jakiś milczący towarzysz podmiotu, a zamieszanie w tej sprawie pogłębił sam Eliot. Jednak Thomas Kinsella przekonująco pokazuje w swojej interpretacji, że dalszy tok poematu świadczy, iż podmiot musi być sam (T. Kinsella, Readings in Poetry, Dublin 2006, s. 40, 48). 
There will be time, there will be time

To prepare a face to meet the faces that you meet (w. 26-27).

I będzie czas, i będzie czas,

Bym przygotował twarz

Na spotkanie tych twarzy, które ty widujesz (Dulęba, w. 26-28).

Eliotowskie „you” w tym miejscu ewidentnie odnosi się do ludzi w ogóle, ma charakter konstrukcji bezosobowej. Nazbyt literalny przekład niepotrzebnie ponawia dystynkcję między „ja” oraz „ty” i sugeruje, że ich doświadczenia społeczne są różne. Dla Dulęby najwidoczniej z wizytą idą faktycznie dwie osoby. Dla porównania wersja Sprusińskiego, choć również dość dosłowna, pod względem gramatycznym daje się odczytać jako słowa kogoś, kto mówi sam do siebie: „na spotkanie twarzy, które spotkasz” (w. 27).

Z kolei Pomorski jeszcze konsekwentniej realizuje chwyt zastosowany przez Eliota. Jego Prufrock, mówiąc o sobie, niekiedy używa drugiej osoby liczby mnogiej, co doskonale oddaje autoironię. I tak „With a bald spot in the middle of my hair” (w. 40) wybrzmiewa jeszcze mocniej jako „Bo łyse plamy w swoich włosach mamy” (na uwagę zasługuje również rym wewnętrzny), zaś „Would it have been worthwhile...? (w. 99) zostaje przetłumaczone „I cóż by... z tego przyszło nam?”.

Brak zdecydowania wybrzmiewa w powtarzanym jak mantra „There will be time”. W poniższym fragmencie zostaje on werbalnie przywołany (indecision) oraz podkreślony przez wyliczenia i powtórzenia brzmieniowe:

And time yet for a hundred indecisions,

And for a hundred visions and revisions,

Before the taking of a toast and tea (w. 32-34).

Abulię Profrocka odtwarzają wszyscy polscy tłumacze, osiągając wszakże różny stopień artyzmu. W przekładzie Dulęby fragment ten należy do najbardziej udanych:

\footnotetext{
A przecież czas na sto niezdecydowań,

$\mathrm{Na}$ sto spostrzeżeń i sprostowań,

zanim podadzą herbatę (w. 33-35).
}

Trzy rzeczowniki odczasownikowe są tu semantycznie dobrze dobrane (choć nie kopiują dosłownie tekstu źródłowego) i blisko współbrzmią. Polski tekst wytwarza w tym miejscu lekki efekt uniezwyklenia, ponieważ rzeczownika niezdecydowanie nie używa się w liczbie mnogiej (analogicznie do indecision). Mimo że Dulęba niepotrzebnie potraktował przysłówek czasu „yet” ('jeszcze') jako spójnik przeciwstawny (przecież), co świadczy o niepełnym zrozumieniu tekstu źródłowego, to i tak z jego tłumaczenia jasno wynika, że Prufrock odwleka decyzję.

Wersja Sprusińskiego jest najmniej satysfakcjonująca pod względem fonicznym i cytowany poniżej fragment ilustruje moją wcześniejszą obserwację o rytmicznych ułomnościach jego tekstu. Co więcej, użyte tu wyrazy nie powracają echem w następnej strofie (u Eliota „In 
a minute there is time / For decisions and revisions", w. 47-48). Słowo decyzje nie nawiązuje brzmieniowo do słowa niepewności - drugą parę wersów spina wprawdzie rym przybliżony, ale w płaszczyźnie dźwiękowej nie łączy się ona z poprzednim segmentem:

Jeszcze czas na sto niepewności,

Sto objawień i poprawek,

Zanim podadzą tost i herbatę (Sprusiński, w. 32-34).

Oto jest czas w minucie

Decyzji i poprawek, które minuta odwróci (Sprusiński, w. 47-48).

Trzej kolejni tłumacze próbują dodatkowymi chwytami podkreślić ów paraliż woli u bohatera poematu. U Pomorskiego niezdecydowanie wyraża dodatkowo czasownik: Prufrock uchyla się od roztrzygnięć. W kolejnym wersie tłumacz stosuje zaś inwersję, stawiając liczebnik w postpozycji: wizji stu.

Czas mój i twój, czas na to,

Żeby uchylić się od stu decyzji,

Od wizji stu i stu rewizji

W oczekiwaniu na grzankę z herbatą (Pomorski, w. 31-34).

U Barańczaka wahanie bohatera zostaje przekazane za pomocą urywków zdań (w. 32: „czas, abyś; czas, abym” - wobec Eliotowskiego „Time for you and time for me”, w. 31). Tłumacz następnie doprowadza niezdecydowanie Prufrocka do granic absurdu, każąc mu wyznać, że może zmienić zdanie nawet na widok grzanek i herbaty, nie zaś, jak u Eliota, zanim je podadzą („Before the taking of a toast and tea”):

Czas, abyś; czas, abym; czas na to

Nie kończące się niezdecydowanie,

$\mathrm{Na}$ to, by mieć coś w planie, lecz wciąż zmieniać zdanie,

Nawet na widok grzanek i filiżanek z herbatą (Barańczak, w. 32-35).

U Boczkowskiego wahań jest tysiąc zamiast stu, zaś strofa zyskuje mocne zakończenie dzięki paronomazji spajającej herbatę z herbatnikiem, który zastępuje oryginalną grzankę („toast”):

I czas na tysiąc wahań wśród decyzji,

$\mathrm{Na}$ tysiąc wizji oraz ich rewizji,

Nim po herbatnik sięgniesz i herbatę (Boczkowski, w. 31-34).

W głosie Prufrocka niezdecydowanie łączy się z przesadną nieśmiałością i skrępowaniem, co pokazuje nawracająca fraza „Do I dare” ('czy śmiem') z dopełnieniem to metafizycznym: „Disturb the universe?" ('niepokoić wszechświat', w. 46), to przyziemnym: „to eat the peach?” ('zjeść brzoskwinię', w. 123). Innym sygnałem wątpliwości jest pytanie „(how) should I presume?” ('czy/jak mógłbym pozwolić sobie?', ww. 54, 61, 68). Te kluczowe wyrażenia pojawiają się we wszystkich polskich wersjach. Trzej tłumacze podchwytują leksykalne rozróżnienie między „dare” i „presume”. Sprusiński i Barańczak wykorzystują dwa czasowniki zwrotne ośmielić się i odważyć się, choć niekoniecznie 
zgodnie z ich rozmieszczeniem w tekście źródłowym (zob. tabela 2). Pomorski trzyma się jednej podstawy słowotwórczej, ale żongluje dwoma czasownikami: śmieć i ośmielić się oraz zwrotem zdobyć się na śmiałość. Dulęba i Boczkowski we wszystkich kontekstach związanych z tym motywem konsekwentnie stosują tylko jeden czasownik, co z kolei zwiększa stopień spójności wewnątrztekstowej. Można zatem uznać, że oba rodzaje zachowań translatorskich sprzyjają wysokiej jakości przekładu.

Tabela 2. Sposoby wyrażania niepewności w poszczególnych przekładach

\begin{tabular}{|c|c|c|c|}
\hline Tłumacz & $\begin{array}{c}\text { Do I dare } \\
\text { Disturb the universe? }\end{array}$ & $\begin{array}{l}\text { Do I dare } \\
\text { to eat a peach? }\end{array}$ & (How) should I presume? \\
\hline Dulęba & $\begin{array}{c}\text { Czy ja się ośmielę } \\
\text { Niepokoić wszechświat? }\end{array}$ & $\begin{array}{c}\text { Czy ośmielę się zjeść } \\
\text { brzoskwinię? }\end{array}$ & $\begin{array}{c}\text { Jakże się więc ośmielę? } \\
\text { I jakże się ośmielę? } \\
\text { Więc ośmielić się muszę? }\end{array}$ \\
\hline Sprusiński & $\begin{array}{c}\text { Czy się ośmielę } \\
\text { Wszechświat niepokoić? }\end{array}$ & $\begin{array}{c}\text { Odważyć się brzoskwinię } \\
\text { zjeść? }\end{array}$ & $\begin{array}{c}\text { Jakże się więc ośmielę? } \\
\text { Jakże się ośmielę? } \\
\text { Czy mam się więc ośmielić? }\end{array}$ \\
\hline Pomorski & $\begin{array}{l}\text { Czy się ośmielę ład } \\
\text { świata zakłócić? }\end{array}$ & $\begin{array}{c}\text { Przedziałek śmiałbym }[\ldots] \text { ? } \\
\text { Brzoskwini zjeść owoc } \\
\text { cały? }\end{array}$ & $\begin{array}{c}\text { Jakże się na śmiałość } \\
\text { zdobyć? [x2] } \\
\text { Miałbym się na śmiałość } \\
\text { zdobyć? }\end{array}$ \\
\hline Barańczak & $\begin{array}{c}\text { Czy się odważę } \\
\text { Zakłóciś spokój } \\
\text { wszechświata - dziś, tutaj? }\end{array}$ & $\begin{array}{c}\text { A jak będzie } \mathrm{z} \text { jedzeniem } \\
\text { brzoskwiń? }\end{array}$ & $\begin{array}{l}\text { Jakże się więc ośmielę? } \\
\text { Czy się odważę w ogóle? } \\
\text { Jakże się więc odważę? }\end{array}$ \\
\hline Boczkowski & $\begin{array}{c}\text { Czy się ośmielę } \\
\text { Wszechświat niepokoić? }\end{array}$ & $\begin{array}{c}\text { Czy brzoskwinię zjeść się } \\
\text { ośmielę? }\end{array}$ & $\begin{array}{c}\text { Jakże się więc ośmielę? } \\
\text { Jakże się ja ośmielę? } \\
\text { Czyż się ośmielę rozpocząć } \\
\text { działanie? }\end{array}$ \\
\hline
\end{tabular}

Podejmowane przez bohatera próby wykrzesania z siebie stanowczości spełzają na niczym. W wersie 80 Prufrock rozważa, czy mógłby doprowadzić do momentu rozstrzygającego i wykonać jakiś decydujący dla swego (potencjalnego) związku uczuciowego ruch („force the moment to its crisis"). Trzej tłumacze, Dulęba, Sprusiński i Boczkowski, mówią w tym miejscu o przemaganiu chwilowej słabości. O ile efekt ogólny pozostaje ten sam - bohaterowi nie udaje się zebrać sił, by zadać pytanie - to jednak pojawia się tu znaczące odstępstwo od oryginału, gdyż tłumaczenia sugerują, iż niemożność działania jest przejściowym, a nie permanentnym stanem podmiotu:

Should I, after tea and cakes and ices,

Have the strength to force the moment to its crisis? (w. 79-80)

Czyżbym teraz, po herbacie, po ciastkach i lodach

Znalazł siłę, by przemóc chwilę tej słabości? (Dulęba, w. 82-83) 
Czyżbym po herbacie, keksach, lodach

Miał siłę przemóc ten słabości moment? (Sprusiński, w. 79-80)

Czy po herbacie, lodach, pośród gości,

Będę miał siłę, by pokonać moment swej słabości? (Boczkowski, w. 79-80)

Pomorskiemu udaje się uniknąć pokazania niemocy bohatera jako stanu chwilowego. Jego Prufrock zapytuje retorycznie, kto w takich okolicznościach nie uległby słabości. Jednak, co w tym przekładzie jest dość wyjątkowe, użyte przez tłumacza sformułowanie brzmi niezręcznie (por. w. 80):

Któż po herbacie, lodzie i ptifurkach zdoła

Oprzeć się, przed słabością nie uchylić czoła? (Pomorski, w. 79-80)

Jedynie Barańczak znajduje odpowiednik w postaci polskiego idiomu o takim samym znaczeniu. Co ciekawe, użyty przezeń zwrot „postawić coś na ostrzu noża” wchodzi w jego przekładzie w grę słowną z wersem poprzednim, gdzie pojawia się inny rodzaj sztućca:

I teraz, gdy łyżeczkę na spodeczek złożę,

Miałbym postawić rzecz na ostrzu noża? (Barańczak, w. 80-81).

Jest jeszcze jeden aspekt niedoszłych (inter)akcji Prufrocka: niemożność porozumiewania się. Odmówiwszy działania i poddawszy tę decyzję analizie, podmiot wiersza stwierdza, że nie jest w stanie się wypowiedzieć. Polscy tłumacze formułują owo rozpoznanie w następujący sposób:

It is impossible to say just what I mean! (w. 104).

Nie potrafię wyrazić mych myśli! (Dulęba, w. 108).

Nie potrafię wyrazić ściśle, co myślałem, (Sprusiński, w. 104).

Rozum wszystkiego nie ogarnia! (Pomorski, w. 104).

Nie wiem, jak to powiedzieć... nie, nie jestem w stanie! (Barańczak, w. 105).

O co mi chodzi, wyrazić nie jestem w stanie! (Boczkowski, w. 104).

Czterej z nich zachowują ów istotny wymiar kondycji podmiotu, lecz nadają mu różne odcienie. Opcja Dulęby daje możliwość odczytania uogólnionego, choć użyty został czasownik w formie dokonanej (wyrazić, a nie wyrażać). U Sprusińskiego podmiot liryczny nie potrafi precyzyjnie wyrazić myśli przeszłej i - być może wskutek wprowadzonej przez tłumacza perspektywy czasowej - nie wydaje się specjalnie tym zmartwiony, co znajduje odbicie w zmianie interpunkcji. Najdramatyczniej brzmi to zaś u Barańczaka, gdyż zmieścił on w jednym wersie aż dwukrotne wyznanie niemoty. Najbliższy oryginałowi wydaje się Boczkowski. Natomiast Pomorski kompletnie zmienia myśl Prufrocka: jako że wers ten kończy enumerację (zob. dłuższy cytat w części 1 analizy), nadmiar rzeczy najwyraźniej przerasta bohatera; motyw oniemienia zostaje zaś pominięty. Przesunięcie semantyczne zostało tu wprowadzone, co dla tego przekładu dość nietypowe, dla uzyskania współbrzmienia: ogarnia - „Jeżeli nawet schemat nerwów rzuci na ekran magiczna latarnia” (w. 105). Dla porównania - Barańczak skłonny jest raczej poświęcić latarnię, a - stawiając w wygłosie miejscownik „na ekranie” - zachowuje i problemy Prufrocka z autoekspresją, i niepokojący „medyczny” obraz z kolejnego wersu, przywołujący początek poematu („Jak pacjent pod eterem na stole”, w. 3). 
Pięć aspektów wybranych jako probierz dla tej kategorii przedstawiam w tabeli 3 oraz na wykresie 2. Badana cecha przyjmuje najwyższą w serii wartość dla przekładu Barańczaka, w którym najwyraźniej osiąga optymalność. Tłumaczenie najnowsze wypada niezgorzej, niemniej linia krzywa nie pozostaje przy nim choćby na tym samym poziomie, nie mówiąc już o tendencji wznoszącej.

Tabela 3. Tematyczny rdzeń niezdecydowania w poszczególnych przekładach

\begin{tabular}{|c|c|c|c|c|c|}
\hline \multirow{2}{*}{ Składniki } & \multicolumn{5}{|c|}{ Tłumacz } \\
\hline & Dulęba & Spusiński & Pomorski & Barańczak & Boczkowski \\
\hline „you and me” & - & + & + & + & + \\
\hline indecision & + & - & + & + & + \\
\hline „dare” / „presume” & $\begin{array}{c}+ \\
\text { (brak zmienno- } \\
\text { ści leksykalnej) }\end{array}$ & + & + & + & $\begin{array}{c}+ \\
+ \\
\text { (brak zmienno- } \\
\text { ści leksykalnej) }\end{array}$ \\
\hline $\begin{array}{c}\text { "force the moment to its } \\
\text { crisis" }\end{array}$ & - & - & $\begin{array}{c}+/- \\
\text { (niezgrabne } \\
\text { sformułowanie) }\end{array}$ & + & - \\
\hline niemożność komunikacji & + & + & - & + & + \\
\hline Wynik:_/10 & 6 & 6 & 7 & 10 & 8 \\
\hline
\end{tabular}

Wykres 2. Tematyczny rdzeń niezdecydowania w serii przekładowej

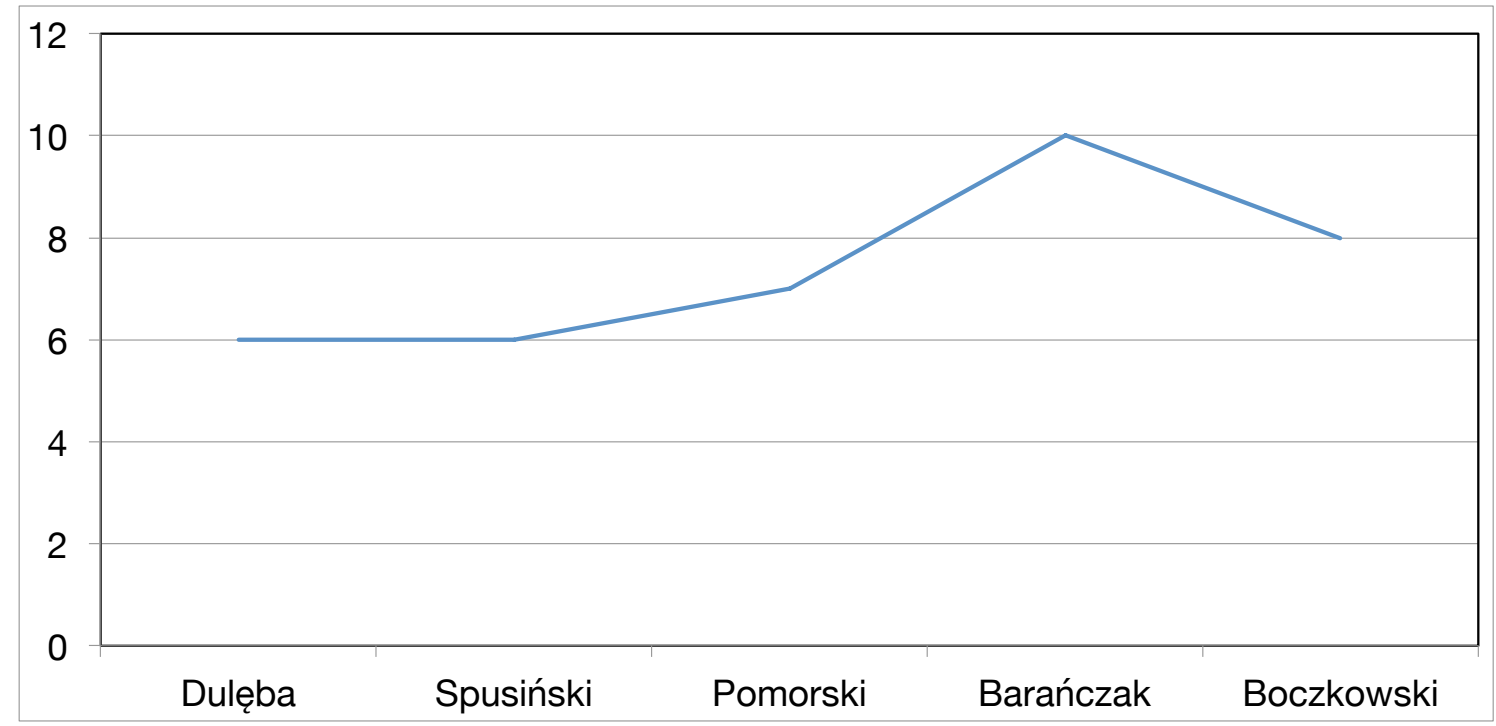




\section{Język i dykcja poetycka}

Jak słusznie podkreślił Hugh Kenner, Prufrock to przede wszystkim głos ${ }^{52}$. Z tej przyczyny językowy kształt tłumaczeń winien zachowywać charakterystyczne brzmienie tego głosu oraz tonację jego niemożliwej pieśni miłosnej. Przełomowe oddziaływanie owego dramatycznego monologu miało swe źródło w jego kolokwialnym idiomie i wyraźnie oralnym charakterze, dzięki którym natychmiast wywierał wrażenie napisanego „w języku odległym od ogólnie przyjętej dykcji poetyckiej"53 - by posłużyć się sformułowaniem Thomasa Kinselli.

Dobry przekład winien zakładać podobną poetykę: wprowadzać potoczny język i mowę idiomatyczną. Niepożądane są natomiast odstępstwa od idiomatyczności - jak zauważył już Wacław Borowy, elementy wypowiedzi Eliota mogą się wydawać „dziwne, acz nie dziwaczne” ${ }^{4}$. Rozważania na ten temat zostaną uzupełnione dodatkowymi przykładami ujętymi przeze mnie w tabeli 4.

Dulęba formułuje swoją wersję w języku raczej neutralnym i standardowym (dla jego czasów) niż kolokwialnym. Na przykład oddaje „sawdust restaurant” (w. 7) jako restaurację, podczas gdy inni tłumacze wolą ekspresyjne knajpy. Żółta mgła z drugiej strofy (w. 16-17) ma u niego wprawdzie mordę, ale neutralny język, podczas gdy jego następcy znów sięgają po bardziej nacechowane rozwiązania. Kiedy Prufrock wyobraża sobie komentarz na temat swoich chudych kończyn (They will say: „But how his arms and legs are thin!”, w. 44), Dulęba odwołuje się do eleganckiego czasownika zeszczupleć, natomiast późniejsze wersje stosują bardziej bezpośrednie schudnąć (lub przymiotnik chude). Do okazjonalnych sygnałów rejestru wysokiego należą w tym najwcześniejszym przekładzie m.in. archaiczny przysłówek zaiste (należący do stylu literackiego, ale nie do biblijnego) oraz czasownik ronić (pytania nad talerzem, w. 31) określany przez współczesne słowniki jako poetycki ${ }^{55}$. Być może w roku 1948 nie wydawały się aż tak książkowe, lecz język Dulęby zasadniczo brzmi bardziej formalnie niż język oryginału. Jednocześnie owa wysoka dykcja bywa tu zakłócana przez słowa czy sformułowania niezbyt zręczne, jak np. kolokacja pościłem znojnie. Pojawia się tu nawet osławiona błędna forma perfuma („perfumą [...] pachnie aksamit”, w. 65) - niewykluczone, że została użyta z intencją ironiczną, jednak nie przystaje do ogólnego sposobu mówienia bohatera, znamionującego osobę wykształconą. Niektóre niezręczności stylistyczne można usprawiedliwić upływem czasu i diachronicznymi zmianami w języku, wszelako rozdział w znaczeniu 'przedziałek we włosach' musiał już wówczas brzmieć staroświecko ${ }^{56}$, dziś zaś budzi rozbawienie.

Sprusiński osiąga wprawdzie pewną potoczność - np. w eliptycznych pytaniach z bezokolicznikiem („Odważyć się brzoskwinię zjeść?”, w. 122) - lecz podważają ten efekt używane przezeń

${ }^{52}$ H. Kenner, Bradley, [w:] T.S. Eliot. A Collection of Critical Essays, red. H. Kenner, Englewood Cliffs, N.J. 1962, s. 36.

${ }^{53}$ T. Kinsella, Readings in Poetry, s. 40.

${ }^{54}$ W. Borowy, Wędrówka nowego Parsyfala. Poezja T.S. Eliota (1936), [w:] Studia i szkice literackie, t. 1, Warszawa 1983, s. 524.

${ }^{55}$ Stownik języka polskiego, red. M. Szymczak, Warszawa 2002.

${ }^{56}$ Miarodajny w tym przypadku Słownik języka polskiego pod redakcją W. Doroszewskiego (Warszawa 1958-1965) odnotowuje znaczenie wyrazu jako już przestarzałe, 〈https://sjp.pwn.pl/doroszewski/rozdzial;5491045.html> [dostęp: 1.09.2018]. 
elementy języka wzniosłego. Powtarzający się spójnik albowiem (por. „For/And I have known,” w. 49, 55, 62 - nawet pierwszy z użytych spójników jest mniej formalny) czy też czasownik wdziać (spodnie) wydają się zbyt uroczyste. Do podwyższenia tonu przyczynia się również zmiana obrazowania: dla uzyskania rymu wieńce plecione przez syreny stają się tu diademami (w. 130). Wątpliwości budzi też połączenie wyrazowe „rozpięty na szpilce” (w. 57) użyte w jednym z pamiętnych obrazów poematu (o którym będzie mowa niżej).

Jerzy Jarniewicz z aprobatą pisze o - jak to nazywa - „demotycznej polszczyźnie” tłumaczeń z Eliota dokonywanych przez Adama Pomorskiego ${ }^{57}$. W Śpiewie miłosnym J. Alfreda Prufrocka istotnie mamy do czynienia z bardzo kolokwialną i idiomatyczną dykcją, obfitującą w celne zwroty. Zwraca uwagę m.in. trafne użycie zdrobnienia chwilka czy wybór konstrukcji składniowej żaden ze mnie prorok (w. 83) jako odpowiednika „I am no prophet”. Na znaczną liczbę udanych rozwiązań translatorskich przypada tu tylko jedno wątpliwe (katachreza) sformułowanie (zob. tabela 4).

Barańczak posługuje się językiem równie - a może nawet bardziej - elastycznym i bogatym. Naturalność polszczyzny potocznej objawia się np. wtedy, gdy oryginalne „and here's no great matter" (w. 83) staje się nonszalanckim wtrąceniem (nie żeby mi zależało). Pewne wątpliwości budzi jedynie wyrażenie $w$ ogóle i $w$ szczególe, które wprawdzie jest idiomatyczne, lecz wydaje się zbyt niskie jako odpowiednik zaimka nieokreślonego „all” w wersach „I am Lazarus, come from the dead, / Come back to tell you all, I shall tell you all" (w. 94-95). Łazarz to bądź co bądź rola, do której Prufrock się przymierza, ale z której rezygnuje, gdyż jest dlań nazbyt wzniosła; wybór Barańczaka zdaje się ową wzniosłość kwestionować.

Boczkowski rozpoczyna swój przekład stylem neutralnym, ale wykazuje inklinację do niepotrzebnego popadania w wyższy rejestr. Na przykład we wszystkich trzech deklaracjach z „I am” („Lazarus”, „no prophet”, „not Prince Hamlet”, w. 94, 83, 111) tłumaczy je za pomocą archaicznej i uroczystej formy złożonej jam („Jam jest Łazarz”, „Jam nie prorok”, „Jam nie książę Hamlet”). Można u niego znaleźć również bardzo przekonujące i naturalne sformułowania, gwoli sprawiedliwości trzeba jednak odnotować, iż niektóre z nich zostały powtórzone za Barańczakiem, z niewielkimi tylko zmianami w gramatyce i szyku wyrazów (zob. przykład w tabeli 4). Zdarzają mu się też kolokacje, które brzmią nienaturalnie, a od czasu do czasu brakuje w tekście znaków przestankowych wymaganych przez polską składnię, jak np. w dwuwierszu o Michale Aniele lub w dwóch zamykających utwór trójwierszach. Nie jest to przy tym systemowa rezygnacja z interpunkcji - z jaką często mamy do czynienia w polskiej poezji współczesnej i którą bardziej konsekwentnie stosuje w swym przekładzie Sprusiński - gdyż przecinek występuje lub znika u Boczkowskiego w podobnych kontekstach, np. przed zdaniem przydawkowym: „głosy które milkną” vs. „oczy, co mnie utrwalą” (w. 52, 56).

${ }^{57}$ J. Jarniewicz, Król Rybak u pani Tumidaj, czyli cały Eliot, „Literatura na Świecie” 2009, nr 5-6 (454-455), s. 375-377. 
Tabela 4. Charakterystyka dykcji poetyckiej w poszczególnych tłumaczeniach

\begin{tabular}{|c|c|c|}
\hline Tłumacz & $\begin{array}{l}\text { Poziom potoczności } \\
\text { i idiomatyczności } \\
\text { przykłady }\end{array}$ & $\begin{array}{c}\text { Wybory niezręczne lub niewłaściwe } \\
\text { (przyczyna) }\end{array}$ \\
\hline Dulęba & $\begin{array}{c}\text { neutralny: restauracja, język, zeszczupleć pod- } \\
\text { wyższony: zaiste, ronić }\end{array}$ & $\begin{array}{c}\text { pościłem znojnie (błędna łączliwość) } \\
\text { perfuma (l. poj. rzeczownika blp) } \\
\text { rozdział (przestarzałe znaczenie) }\end{array}$ \\
\hline Sprusiński & $\begin{array}{c}\text { lekko kolokwialny: } \\
\text { knajpy, rozmówki, } \\
\text { spódnice wleczone przez posadzki } \\
\text { potoczna składnia: } \\
\text { Odważyć się brzoskwinię zjeść? }\end{array}$ & $\begin{array}{c}\text { albowiem (wysoki rejestr) } \\
\text { spodnie... wdzieję (wysoki rejestr) } \\
\text { rozpięty na szpilce (błędna łączliwość) }\end{array}$ \\
\hline Pomorski & $\begin{array}{l}\text { potoczny, wysoce idiomatyczny: } \\
\text { zakazane uliczki, przyszpilić formułka, } \\
\text { poduczyć (twarz), chwilka, } \\
\text { żaden ze mnie prorok, Fagas }\end{array}$ & $\begin{array}{l}\text { suknie w powłóczystym stylu } \\
\text { (katachreza/nadużycie semantyczne) }\end{array}$ \\
\hline Barańczak & $\begin{array}{l}\text { potoczny, wysoce idiomatyczny: } \\
\text { Podstawił grzbiet pod sadzę, prószq̨ca z kominów } \\
\text { (w. 19), ułożenie twarzy, prorok ze mnie jest } \\
\text { żaden (nie żeby mi zależało), strach mnie brał, } \\
\text { a jak będzie z...? }\end{array}$ & $\begin{array}{l}\text { w ogóle i w szczególe } \\
\text { (zbyt nonszalanckie w danym kontekście) }\end{array}$ \\
\hline Boczkowski & $\begin{array}{l}\text { neutralny, umiarkowanie idiomatyczny: } \\
\text { Grzbiet podstawia pod sadze prószące } \\
\text { z kominów (w. 19) } \\
\text { podwyższony: wykrzyknik O, powtarzana } \\
\text { forma czasownikowa jam }\end{array}$ & $\begin{array}{c}\text { łzy wzajemne (błędna kolokacja, } \\
\text { niemotywowana oryginałem) } \\
\text { łatwe narzędzie (kalka) }\end{array}$ \\
\hline
\end{tabular}

Styl The Love Song jest przeważnie kolokwialny, jednak zdarzają się w poemacie zmiany tonu. W efekcie w niektórych fragmentach podwyższony rejestr będzie nie tylko uzasadniony, ale wręcz pożądany ${ }^{58}$. Na przykład Barańczakowy adwersarz jako metonimiczna reprezentacja równie wyszukanego „insidious intent” (w. 9, 'podstępny zamiar') nie narzuca fałszywego tonu. Najwyraźniejszy kontrast wybrzmiewa w zakończeniu poematu, gdzie podmiot mówiący przerzuca się od autoironii do nieomalże romantycznej dykcji tęsknoty:

I have seen them [mermaids] riding seaward on the waves

Combing the white hair of the waves blown back

When the wind blows the water white and black. (w. 126-128)

\footnotetext{
${ }^{58}$ Kontekst biblijny oraz dystans, jaki wytwarza przytoczenie, usprawiedliwiają podwyższenie dykcji w wypowiedzi przypisanej Łazarzowi (w. 94-95). Podobnie nie dziwi, że w wersie 37, „And indeed there will be time”, trzej tłumacze oddają ,indeed” jako biblijne zaprawdę.
} 
W cytowanym trójwierszu dochodzi do głosu liryczna intensywność nieosiągalna dla samego Prufrocka, którą może on tylko wyobrażać sobie z pewnego dystansu. We wszystkich przekładach daje się zauważyć owa zmiana tonu, jednak zwrot od potoczności ku poetyczności najsilniej wyrażony jest u Pomorskiego, który stosuje zawiłą (acz w pełni czytelną) zlatynizowaną składnię, przywodzącą na myśl polszczyznę poetów renesansowych:

Na falach, w morze, widziałem, pędziły,

Przeciwnej wichrząc białe włosy fali;

Toń biało-czarną wiatr podnosił z dali (Pomorski, w. 126-128).

Szczególną uwagę zwraca tu przestawienie orzeczenia widziałem w zdaniu głównym oraz odłączenie epitetu w wyrażeniu przeciwna fala i wstawienie przed rzeczownikiem całej frazy imiesłowowej. Tego rodzaju strategia znakomicie koresponduje z charakterystycznym dla wczesnych utworów Eliota wpływem składni i frazeologii języka francuskiego. Chociaż czasem uznaje się takie powinowactwo za czynnik ułatwiający tłumaczenie na francuski ${ }^{59}$, to w zasadzie nie sposób go oddać w innych językach, przynajmniej bez popadania w afektację. Subtelna latynizacja Pomorskiego znakomicie, jak się wydaje, tę cechę kompensuje.

O rozpoznawalności poetyckiego głosu Eliota stanowi także używanie specyficznych sformułowań i obrazów, rzucających wyzwanie postromantycznym kliszom i celowo niepokojących. Warto przyjrzeć się, jak w polskich przekładach potraktowane zostały reprezentatywne pod tym względem wersy 56-57, w których mowa o groźbie cudzego spojrzenia. Jean Ward zauważa, iż dwie najwcześniejsze wersje nie w pełni przekazują okrucieństwo oryginalnego obrazu ${ }^{60}$. Porównanie z tekstem źródłowym pozwala potwierdzić jej rozpoznanie:

The eyes that fix you in a formulated phrase,

And when I am formulated, sprawling on a pin (w. 56-57).

Oczy, co cię utwierdzą w ułożonym zdaniu,

I skoro jestem przytwierdzony, przybity szpilką (Dulęba, w. 59-60).

Oczy co cię utrwalą w formułce zdania,

I gdy jestem nazwany, rozpięty na szpilce (Sprusiński, w. 56-57).

U Eliota spojrzenie przeszywa i unieruchamia (te znaczenia spotykają się w czasowniku fix), a bycie „sformułowanym” to stan niewątpliwie bolesny. Dulęba wprowadza grę czasowników utwierdzać i przytwierdzać, jednak pierwszy z nich niesie konotacje raczej pozytywne. Sprusiński wybiera czasownik utrwalać, który znaczeniowo może się kojarzyć z cementowaniem albo nawet przechowywaniem czegoś w formalinie, ale ma liczne znaczenia waloryzowane

\footnotetext{
${ }^{59}$ Zob. J.F. Hooker, T.S. Eliot Poems in French..., s. 45-48. Wskazując przejawy tego rodzaju wpływu, Hooker po części opiera się na wcześniejszych badaniach Elizabeth W. Schneider (J.F. Hooker, T.S. Eliot Poems in French..., s. 47).

${ }^{60} \mathrm{~J}$. Ward, Autoaluzja i inne cechy poezji T.S. Eliota, czyli czy tłumacz jednego wiersza musi znać cała twórczość autora?, [w:] Przekładajac nieprzekładalne, [t. 1], red. O. Kubińska, W. Kubiński, T.Z. Wolański, Gdańsk 2000, s. 342, 349-350.
} 
dodatnio, jak 'nadawać trwałość', 'zachować w pamięci' ${ }^{\text {'1 }}$. Dobór takich mało opresyjnych czasowników nie został skompensowany w kolejnym wersie, gdzie oczy nie są już profilowane jako wykonawca czynności. Skuteczność rozwiązań przyjętych przez Sprusińskiego osłabia ponadto nielogiczne i morfologicznie niespójne połączenie rozpięty na szpilce.

Postulowane przez Ward połączenie w przekładzie dosłowności i metaforyczności ${ }^{62}$ bezsprzecznie udaje się osiągnąć Pomorskiemu:

Gdy patrzą, jaką by mnie przyszpilić formułką,

A kiedy sformułują, nabiją na szpilę (Pomorski, w. 56-57).

Oczy „przyszpilają” formułkami, a więc zadają ból. Wzmocnienie efektu zostaje osiągnięte poprzez użycie par wyrazów pokrewnych: szpila - przyszpilić, formułka - formułować, które tworzą jakby pewnego rodzaju „sieć” usidlającą podmiot-owada. Nad wyraz trafnie wykorzystuje również Pomorski lekceważące zdrobnienie formułka w sąsiedztwie augmentativum szpila, dzięki czemu ta ostatnia jest konceptualizowana jako większa i w związku z tym zadająca większy ból. Poza tym szpila metaforycznie przywołuje uszczypliwość.

Z kolei Barańczak dezautomatyzuje lekturę, ogrywając i odświeżając zastaną w języku łączliwość wyrazów „oczy” i „zamykać”. Podmiot zostaje uwięziony w formule, otrzymuje - niczym eksponat wystawowy - numerek i dopiero wtedy pojawia się obraz przyszpilenia, unieruchomienia:

Oczy, które mnie zamkną w gotowej formule,

I co wtedy? Gdy zamkną, numerkiem oznaczą,

Gdy, przyszpilony, już nie będę mógł uciekać (Barańczak, w. 56-58).

Boczkowski powraca do użytego przez Sprusińskiego czasownika utrwalać, który Ward uznała za nie dość mocny, i uzyskuje rym, każąc Prufrockowi wyobrażać sobie siebie nabitego na szpikulec:

Oczy, co mnie utrwalą w utartej formule,

A gdy mnie przeszywając wbiją na szpikulec,

Gdy przyszpilony wiję się na ścianie (Boczkowski, w. 56-58).

Rzeczownik szpikulec kojarzy się z czymś większym niż szpilka używana do umocowywania martwych owadów czy robaków w gablotach. Ponadto zestawienie z imiesłowem przyszpilony narusza logikę i łączliwość - na szpikulec można coś nabić lub nadziać. Obecność błędów osłabia wrażenie opresyjności i w sumie obraz ów najlepiej uchwycili w swych tłumaczeniach Pomorski oraz Barańczak.

\footnotetext{
${ }^{61}$ Por. Stownik języka polskiego (red. M. Szymczak).

${ }^{62} \mathrm{~J}$. Ward, Autoaluzja i inne cechy poezji T.S. Eliota..., s. 350.
} 
Oczywiście ten pojedynczy fragment nie może być miernikiem sukcesu poszczególnych translatorskich prób odtworzenia specyficznego Eliotowskiego obrazowania, ale stanowi dość reprezentatywną w tym względzie próbkę analizowanych tekstów docelowych. Choć trudno byłoby stwierdzić, że którykolwiek z polskich tłumaczy lekceważy poetykę oryginału, to jednak Dulęba i Sprusiński raz po raz osłabiają wyrazistość specyficznych sformułowań Eliota. Barańczak odtwarza ogólny sens obrazu, lecz często - jak to ma w zwyczaju - nie waha się wprowadzić całkiem nowego mikroobrazu lub zdezautomatyzować odbioru poprzez zastosowanie ulubionej przezeń przerzutni (zob. np. w. 29-30 cytowane w części 4). Boczkowskiemu niejednokrotnie zdarza się dla zbudowania schematu rymowego sięgać do substytucji lub amplifikacji, co niekiedy skutkuje naruszeniem autorskiej dykcji. Przy porównywaniu poszczególnych rozwiązań często - choć nie zawsze - najlepiej wypada Pomorski.

Powyższe aspekty dostarczają w tej części rozważań materiału pomiarowego ujętego w tabeli 5 i na wykresie 3. Gwoli zwięzłości nie referuję tu przeprowadzonych przeze mnie analiz w całości, ograniczając się do przedstawienia wyników. Reprezentatywne dla poszczególnych tłumaczeń przykłady paronomazji, które również wpływają na brzmienie głosu Eliota, przytaczałam w innych częściach artykułu.

Tabela 5. Cechy językowe poematu w poszczególnych przekładach

\begin{tabular}{|c|c|c|c|c|c|}
\hline \multirow{2}{*}{ Składniki } & \multicolumn{5}{|c|}{ Tłumacz } \\
\hline & Dulęba & Spusiński & Pomorski & Barańczak & Boczkowski \\
\hline dykcja potoczna & - & + & + & + & - \\
\hline idiomatyczność & - & 0,5 & + & + & 0,5 \\
\hline $\begin{array}{l}\text { trafność użycia } \\
\text { elementów } \\
\text { nacechowanych } \\
\text { stylistycznie }\end{array}$ & + & - & + & 0,5 & + \\
\hline $\begin{array}{l}\text { odtworzenie } \\
\text { obrazowania }\end{array}$ & 0,5 & 0,5 & + & + & 0,5 \\
\hline paronomazje & - & - & + & + & + \\
\hline Wynik:_/10 & 3 & 4 & 10 & 9 & 6 \\
\hline
\end{tabular}




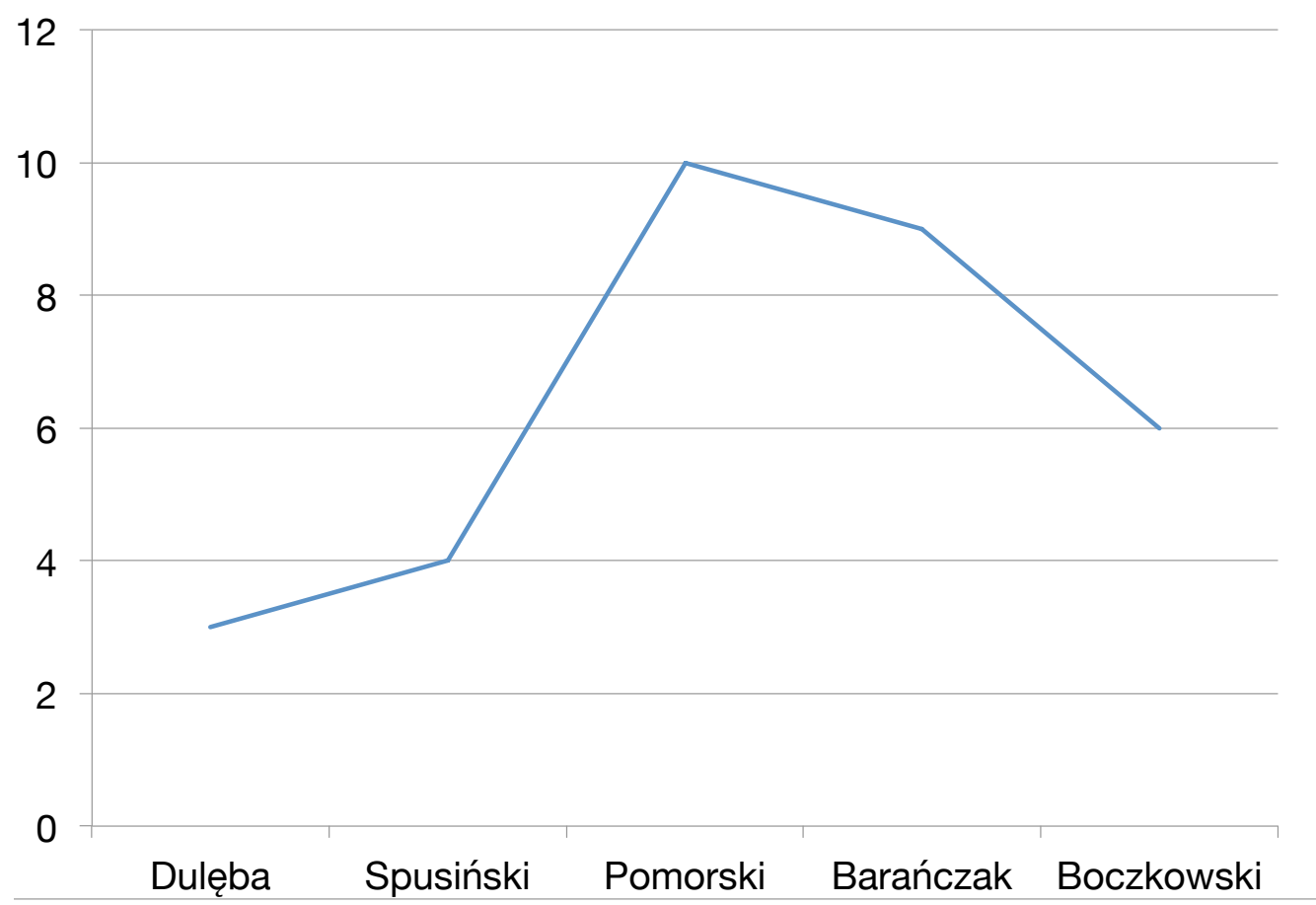

Wykres 3. Cechy językowe w badanej serii translatorskiej

\section{Intertekstualność}

Odniesienia intertekstualne mają kluczowe znaczenie dla poematu i stanowią nieodłączną cechę szczególnej Eliotowskiej dykcji, która obfituje w subtelne, rozproszone sygnały dialogowości ${ }^{63}$. W The Love Song służą one charakteryzowaniu podmiotu mówiącego jako osoby wykształconej, a także jego autoprezentacji. Począwszy od motta, interteksty wywierają wpływ na oczekiwania odbiorcy, aktywują konteksty i ramy interpretacyjne.

Spośród tworzących gęstą sieć aluzji wybieram do analizy osiem. Reprezentują one różne sfery odniesien, a ich rozpiętość umożliwia miarodajną ocenę tego aspektu tłumaczeń. Adekwatny przekład intertekstualności polega nie na uzyskiwaniu formalnej odpowiedniości między poszczególnymi elementami, ale na przekazywaniu ich pragmatycznych implikacji, stąd w przypadku hermetycznej aluzyjności Eliota będę brała pod uwagę również pewne środki dodatkowe, takie jak przypisy objaśniające w tekstach docelowych (o ile tego rodzaju paratekst pochodzi od tłumacza, a nie od redakcji).

We wszystkich pięciu przekładach zachowane zostało motto, które poprzez przywołanie postaci Guida da Montefeltro z poematu Dantego ewokuje sytuację uwięzienia w piekle, konteksty skrytości i dwoistości. W każdym przypadku wskazano w przypisie, skąd pochodzi ów fragment, a także podano cytat w kanonicznym polskim tłumaczeniu Boskiej komedii autorstwa Edwarda Porębowicza.

Jeśli chodzi o sygnały intertekstualne pojawiające się w samym tekście poematu Eliota, najbardziej czytelne z nich również występują we wszystkich wersjach. Gdy Prufrock stwierdza, że nie 
jest prorokiem, choć widział swą głowę na tacy (w. 82-83), aluzja do Jana Chrzciciela pozostaje słyszalna w każdej z nich mimo różnic w tłumaczeniu słowa „platter” (pótmisek, taca, misa). Również nawiązanie do Łazarza (w. 94) nie przysporzyło tłumaczom żadnych trudności. Autoprezentacji podmiotu mówiącego dopełnia jeszcze jedno negatywne zestawienie. Zamiast jako Hamlet, Prufrock identyfikuje się w kilkuwersowej charakterystyce jako 'dworzanin z orszaku', 'prawie Błazen' (,an attendant lord”, „almost the Fool”, w. 112, 119). W wersjach Dulęby i Boczkowskiego jedno z określeń nie pasuje do osoby Poloniusza - wyobrażona postać pojawia się w zaledwie paru scenach, zamiast je otwierać (por. „start a scene or two”, w. 113); wszakże inne wskazówki pozwalają na właściwą identyfikację. Opisy w pozostałych przekładach również ewokują Poloniusza.

Mimo że motyw syren także nie powinien sprawiać problemów, tylko trzech tłumaczy użyło właśnie rzeczownika syreny jako ekwiwalentu słowa mermaids (w. 124). Dulęba na przykład pisze o śpiewach topielic (w. 130); wprawdzie sam motyw kuszącego śpiewu ewokuje syrenią pieśn, lecz wybór leksykalny, nakierowany na uzyskanie rymu przybliżonego (flaneli - topielic), nie wydaje się fortunny. Pomorski, o dziwo, wybiera pieszczotliwe zdrobnienie syrenka (w. 124), kojarzące się raczej z baśnią dla dzieci, a tym samym osłabiające powagę fragmentu. Jest to decyzja dość zaskakująca, zwłaszcza wobec majestatycznej tonacji, w jakiej tłumacz ten ujął opis syren pędzących na falach (cytowany w trzeciej części artykułu), a także wobec komentarza ${ }^{64}$, w którym Pomorski przywołuje jako możliwy kontekst Pieśn Johna Donne’a (o incipicie „Ten, kto gwiazdę w locie schwyta..." w tłumaczeniu Barańczaka, zawierającym niezdrobniałą formę Syreny).

Wersy 28-29 scalają dwie aluzje, biblijną i klasyczną. Zwłaszcza ta druga, praktycznie wtopiona we frazę, w tok poematu, jest słabo widoczna:

There will be time to murder and create

And time for all the works and days of hands (w. 28-29)

Będzie czas, by zabijać i tworzyć,

Czas na działanie i czas rąk,

Które [...] (Dulęba, w. 29-31)

Czas zabijania i tworzenia,

Czas pracy i czas dłoni (Sprusiński, w. 28-29)

Czas zabijania i czas płodzenia,

Prac i dni wszystkich czas nastanie (Pomorski, w. 28-29)

Nastanie czas na mord i czas na tworzenie, nastanie

Czas na prace i dnie ludzkich rąk (Barańczak, w. 29-30)

Będzie czas zabijania oraz czas tworzenia

I czas na dni i prace (Boczkowski, w. 28-29).

W źródłowej frazie „There will be time to murder and create” (w. 28) tylko odlegle słychać echo słów z Księgi Eklezjasty (Koh 3,3) (Biblia Króla Jakuba ${ }^{65}$ i American Standard Version ${ }^{66}$ mają w tym

${ }^{64}$ T.S. Eliot, W moim poczq̨tku jest mój kres, s. 330.

${ }^{65}$ The Old Testament. The Authorised or King James Version of 1611, introd. G. Steiner, London 1996.

${ }^{66}$ The Holy Bible. American Standard Version, [w:] Bible Gateway, <https://www.biblegateway.com/passage/?search= Ecclesiastes+3\&version=ASV > [dostęp: 1.09.2018]. 
miejscu „There is... A time to kill, and a time to heal”). Niemniej jednak w kontekście całej Eliotowskiej enumeracji nawiązanie do słów Koheleta „wszystko ma swój czas” nasuwa się w sposób naturalny. To, czy owa fraza będzie w polszczyźnie odbierana jako biblijna, zależy od użytej struktury gramatycznej: po słowie czas musi nastąpić rzeczownik odsłowny w dopełniaczu. Dulęba stosuje konstrukcję ze zdaniem okolicznikowym celu („czas, by”, w. 29). W wersji Sprusińskiego, owszem, słychać echo biblijnej polszczyzny, w której parafrazowane przez Eliota sformułowanie oddaje się jako „czas zabijania i czas leczenia”67. Boczkowski dokonuje tych samych wyborów leksykalnych i strukturalnych, dodatkowo wzmacniając efekt przez powtórzenie, na wzór biblijny, rzeczownika czas: „czas zabijania oraz czas tworzenia” (w. 28). Pomorski idzie za strukturą biblijną, ale interpretuje „tworzenie” jako „płodzenie”, co nie podważa związku tego wersu z biblijnym pretekstem, jednak zawęża sensy wpisane w tekst Eliota. Barańczak wybiera rozwiązanie przeciwne: leksykalnie podąża raczej za Eliotem niż za Biblią, używając słowa „mord” (oraz „tworzenie”), lecz przyimkowa składnia w jego wersji („czas na...”) raczej nie wywołuje u docelowego odbiorcy skojarzenia z Biblią.

Natomiast aluzję do tytułu dzieła Hezjoda Prace i dni (w tradycji ang. Works and Days) zachowali Pomorski i Barańczak. Boczkowski odwrócił kolejność rzeczowników (dni i prace), by uzyskać rym (prace - tacę), a wyjaśnienie na temat tego nawiązania intertekstualnego zawarł w przypisie ${ }^{68}$. Inwersja sprawia, że bez takiego wyjaśnienia czytelnikowi byłoby niezmiernie trudno dostrzec owo nawiązanie, zatem paratekst zastępuje w tym miejscu zatarty sygnał intertekstualności. Nie można jednak uznać, iż dzięki temu aluzja została pomyślnie odtworzona w przekładzie. Dulęba i Sprusiński zgodnie opuszczają „days” i łączą pojęciowo pracę (a w przypadku Dulęby wręcz „działanie”) bezpośrednio z rękoma (hands), które istotnie są ważne dla obrazowania, gdyż za chwilę upuszczą na talerz Prufrocka fatalne pytanie... („the works and days of hands / That lift and drop a question on your plate").

Jeśli przekład odtwarza aluzję do tytułu dzieła klasycznego w sposób zgodny z tradycją obowiązującą w kulturze docelowej, wykształcony odbiorca tłumaczenia ma wszelkie szanse, by ją rozpoznać. Inaczej rzecz się ma z reminiscencjami z angielskiej poezji metafizycznej, które w polszczyźnie raczej nie rezonują. Tak dzieje się na przykład wówczas, gdy w słowach Eliota pobrzmiewa echo wiersza Andrew Marvella:

To have squeezed the universe into a ball

To roll it toward some overwhelming question (Eliot, w. 92-93).

Let us roll all our strength, and all

Our sweetness, up into one ball (Marvell, w. 41-42) ${ }^{69}$.

Dulęba nie zachował powyższej aluzji. W czasie gdy tłumaczył on The Love Song, nie istniała wprawdzie jeszcze polska wersja To His Coy Mistress, ale użycie przezeń słowa gałka sugeruje, że w ogóle nie był świadom tego nawiązania:

\footnotetext{
${ }^{67}$ Występuje ono zarówno w Biblii Tysiąclecia, jak i w tłumaczeniu Jakuba Wujka, które ukształtowało polską frazeologię religijną.

${ }^{68}$ T.S. Eliot, Szepty nieśmiertelności, s. 102.

${ }^{69}$ A. Marvell, To His Coy Mistress, [w:] Seventeenth-Century Poetry, red. P. Driver, Harmondsworth 1996, s. 80.
} 
Ściskać wszechświat do rozmiarów gałki

I toczyć ją do nieodpartych pytań (Dulęba, w. 96-97).

U Sprusińskiego Prufrock również mówi o „zgniataniu wszechświata w gałkę” (w. 92), choć gdy powstawał ten z kolei przekład, zdążyło się już ukazać w roku 1963 polskie tłumaczenie wiersza Marvella autorstwa Jerzego S. Sity, w którym odpowiednie wersy otrzymały następujące brzmienie: „Tedy Moc całą, Chęć i Słodycz wszelką / Utoczmy razem w jedną kulę wielką" W swoim posłowiu Sprusiński wskazuje wprawdzie źródło aluzji ${ }^{71}$, ale jedynym wspólnym elementem dwóch interesujących nas fragmentów polskich jest w tym przypadku czasownik (u)toczyć, bezpośrednio sugerowany przez oba teksty źródłowe (roll). Kiedy przekłady Dulęby i Sprusińskiego zostały przedrukowane w krytycznej edycji wyboru poezji Eliota, redaktorzy nie opatrzyli tego miejsca w poemacie żadnym komentarzem o nawiązaniu do metafizycznego wiersza Marvella, co może oznaczać, że w Polsce nawet badacze nie zdawali sobie sprawy z intertekstualnej doniosłości rzeczonego wersu. Dopiero Pomorski wprowadził do serii motyw utaczania kul(k)i, tworząc werbalne echo między swoją wersją sformułowania Eliota i dwuwierszem Marvella, zacytowanym przezeń w komentarzu we własnym, jak się zdaje, przekładzie:

Że małą kulkę utoczywszy z globu,

Do przygnębiającego turlasz ją pytania (w. 92-93).

Tę słodycz, co w nas wzbiera czule,

I moc utoczmy w jedną kulę (Marvell, Do pani cnotliwej) ${ }^{72}$.

Stanisław Barańczak znalazł się w tym przypadku w wyjątkowej sytuacji, gdyż jest on również autorem przekładu To His Coy Mistress. W jego Prufrocku pogłos wiersza Marvella nie jest wszakże zbyt wyraźny. Porównajmy:

Wgryzać się w taką kwestię z uśmiechem, zgniatać w kulę

Wszechświat i toczyć go w stronę jakichś przygważdżających pytań (Barańczak/Eliot, w. 93-94)

Całą więc naszą moc i całą czule

Wezbraną słodycz zlepmy w jedną kulę (Barańczak/Marvell, w. 41-42) ${ }^{73}$.

Wprawdzie pojawia się tu leksem kula, brakuje jednak polskiego odpowiednika słowa roll (toczyć), którego użył Marvell. Efekt podobieństwa Barańczak mógł wzmocnić przez zastosowanie w Prufrocku czasownika lepić, którym posłużył się wcześniej w przekładzie To His Coy Mistress, lecz wybrał czasownik zgniatać, najbliższy obrazowo oryginalnemu Eliotowskiemu „squeeze”. Barańczakowe tłumaczenie wiersza Marvella pojawia się raz jeszcze w polskiej serii Pieśni miłosnych...: autor najnowszej wersji przywołuje Do nieskorej bogdanki w komentarzu wyjaśniającym

${ }^{70}$ A. Marvell, Do cnotliwej kochanki, przeł. J.S. Sito, [w:] Poeci języka angielskiego, red. H. Krzeczkowski, J.S. Sito, J. Żuławski, t. 1, Warszawa 1969, s. 701.

${ }^{71}$ M. Sprusiński, Poeta wielkiego czasu, s. 239.

${ }^{72}$ T.S. Eliot, $W$ moim poczq̨tku jest mój kres, s. 329. Pomorski zaproponował tłumaczenie innego, dłuższego fragmentu wiersza Marvella w przypisach do swego przekładu The Waste Land, zob. „Kwartalnik Artystyczny” 1995, nr 2 (6), s. 14.

${ }^{73}$ A. Marvell, Do nieskorej Bogdanki, przeł. S. Barańczak, [w:] Antologia angielskiej poezji metafizycznej XVII stulecia, tłum. i red. S. Barańczak, Warszawa 1982, s. 247. 
omawianą aluzję $e^{74}$. Jednak w samym przekładzie Boczkowski również wybiera czasowniki toczyć i zgnieść, uchylając się od podkreślenia faktycznego związku między tekstami Eliota i Marvella:

Wszechświat zgnieść w jedną kulę

I toczyć go w kierunku ostatecznych pytań (Boczkowski, w. 92-93).

W poemacie Eliota odniesienia do innych tekstów z reguły charakteryzuje niski poziom eksplicytności ${ }^{75}$, niektóre można w zasadzie uznać za ukryte. Rozproszone, fragmentaryczne i zdekontekstualizowane, mogą umykać uwadze odbiorcy sekundarnego, nawet gdy zostaną w tłumaczeniu oddane z należytą starannością. Mając to na względzie, wolno traktować dodatkowe wyjaśnienia na temat powiązań intertekstualnych jako elementy podnoszące jakość przekładu ${ }^{76}$ pod warunkiem, że kompensują one różnice w wyposażeniu poznawczym, a nie są tylko próbą uchylenia się przez tłumacza od odtworzenia takiego związku. Zatem uwzględniam w tabeli 6 okoliczność, że Pomorski i Boczkowski dostarczają odbiorcom swoich tłumaczeń obszernych komentarzy, przy czym wiele z nich służy właśnie przekazywaniu informacji o źródłach aluzji ${ }^{77}$.

Obaj wzmacniają również ogólną aurę intertekstualną przekładu, wprowadzając dodatkowe sygnały o charakterze kompensacyjnym. U Boczkowskiego wers 49 - „Bo już poznałem wszystkie dni i nocy sprawy" - osobliwie rezonuje z pierwszą linijką pieśni religijnej Franciszka Karpińskiego „Wszystkie nasze dzienne sprawy”78. Tłumacz sam potwierdza tę zbieżność w komentarzu ${ }^{79}$. Wprawdzie zabieg ten wynika, jak się zdaje, z poszukiwania rymu do słynnego wersu „I have measured out my life with cofee spoons" (w. 51) kończącego się w wersji polskiej frazą tyżeczkami kawy, ale tak czy inaczej wzmacnia dykcję aluzyjną. The Love Song w przekładzie Pomorskiego wręcz rozpoczyna się nutą rozpoznawalną dla polskich czytelników poezji. Zamiast „Let us go then, you and I” mamy tu „Cóż zatem, pójdź ze mną”, ewokujące łaciński zwrot Vade mecum i tytuł cyklu poetyckiego Cypriana Kamila Norwida. Gdy w grę wchodzi tłumaczenie intertekstualności, naturalizacja jest zabiegiem często z góry wykluczanym lub krytykowanym przez badaczy przekładu ${ }^{80}$, jednak w przypadku takiego autora jak Eliot bywa niekiedy chwalona ${ }^{81}$. Zważywszy na to, jak wielką rolę odgrywa intertekstualność w poetyce Eliota, wplecenie owych rodzimych nut do dwóch

${ }^{74}$ T.S. Eliot, Szepty nieśmiertelności, s. 103.

${ }^{75}$ Por. typologię odniesień ze względu na stopień jawności: A. Majkiewicz, Intertekstualność - implikacje dla teorii przekładu. Wczesna proza Elfriede Jelinek, Warszawa 2008, s. 22-26 i passim.

${ }^{76}$ Anna Majkiewicz stwierdza, że tłumaczenie z definicji powinno się charakteryzować zwiększoną w porównaniu z tekstem źródłowym jawnością informacji. Amplifikacje i praktyki metatekstualne są immanentnymi cechami przekładu (Intertekstualność - implikacje dla teorii przekładu..., s. 306-307).

${ }^{77}$ Wiele uwagi komentarzom Pomorskiego, zwłaszcza tym, które towarzyszą Ziemi jałowej, poświęca Jarniewicz (Król Rybak u pani Tumidaj, czyli cały Eliot, s. 378-381). Pozwolę sobie podkreślić, iż komentarze do Prufrocka są cenne i miarodajne, mimo potknięcia ze sformułowaniem „dying fall” (w. 52) błędnie powiązanym z Jak wam się podoba Szekspira zamiast z Wieczorem Trzech Króli (zob. T.S. Eliot, W moim początku jest mój kres, s. 329). Barańczak ogranicza się do przypisu z polską wersją motta i nie opatruje tekstu komentarzami, choć czyni to w odniesieniu do niektórych innych utworów w swojej antologii.

${ }^{78}$ F. Karpiński, Pieśń wieczorna, [w:] F. Karpiński, Wybór wierszy, Warszawa 1986, s. 100.

${ }^{79}$ T.S. Eliot, Szepty nieśmiertelności, s. 102.

${ }^{80} \mathrm{Co}$ bywa wyrażane implicite, jak w finalnej konkluzji Majkiewicz, iż intertekstualność w przekładzie wymusza egzotyzację (Intertekstualność - implikacje dla teorii przekładu, s. 303).

${ }^{81}$ Zob. J. Gutorow, Przeciw dosłowności. Notatki na marginesie polskiego przekładu „Mercian Hymns” Geoffreya Hilla, [w:] Przekładając nieprzekładalne, t. 3, red. O. Kubińska, W. Kubiński, Gdańsk 2007, s. 130; Jarniewicz zwraca uwagę, że reintertekstualizacja stanowi uchwytną, choć sporadycznie występującą cechę zbioru przekładów Pomorskiego, rezultaty poszczególnych decyzji oceniając to pozytywnie, to ze sceptycyzmem (Król Rybak u pani Tumidaj, czyli cały Eliot, s. 381-383). 
polskich wersji Love Song wypada raczej docenić niż potępić. Pozostali tłumacze nie podjęli prób kompensowania sygnałów intertekstualności, które w przekładzie uległy zatarciu lub implicytacji, poprzez wprowadzenie dodatkowych odwołań do kultury źródłowej, docelowej lub trzeciej.

Osiem przeanalizowanych wykładników dialogowości oraz dwie strategie stanowią materiał podsumowany w tabeli 6 . Krzywa wykresu wykazuje w tym przypadku najbardziej wzrostowy charakter w porównaniu z wcześniejszymi, lecz i tu nie obserwujemy stałego wznoszenia się.

Tabela 6. Odtworzenie intertekstualności w poszczególnych przekładach

\begin{tabular}{|c|c|c|c|c|c|}
\hline \multirow{2}{*}{ Komponenty } & \multicolumn{5}{|c|}{ Tłumacz } \\
\hline & Dulęba & Spusiński & Pomorski & Barańczak & Boczkowski \\
\hline $\begin{array}{c}\text { S'io credesse } \\
\text { (Dante) (motto) }\end{array}$ & + & + & + & + & + \\
\hline $\begin{array}{l}\text { time to murder and create } \\
\quad(\text { Koh } 3,1-8)(\text { w. 28) }\end{array}$ & - & + & $(+)$ & $(+)$ & + \\
\hline $\begin{array}{l}\text { works and days } \\
\text { (Hezjod) (w. 29) }\end{array}$ & - & - & + & + & $\begin{array}{c}- \\
\text { (inwersja) }\end{array}$ \\
\hline $\begin{array}{l}\text { head upon a platter } \\
\text { (w. 82) }\end{array}$ & + & + & + & + & + \\
\hline $\begin{array}{l}\text { squeezed... into a ball } \\
\text { (Marvell) (w. 92-93) }\end{array}$ & - & - & + & + & + \\
\hline Łazarz (w. 94) & + & + & + & + & + \\
\hline $\begin{array}{c}\text { attendant lord } \\
\text { (Poloniusz) (w. 114-119) }\end{array}$ & $(+)$ & + & + & + & $(+)$ \\
\hline mermaids (w. 124) & - & + & $\begin{array}{c}- \\
\text { (syrenki) }\end{array}$ & + & + \\
\hline kompensacje & - & - & $\begin{array}{c}+\underset{+}{(p o ́ j d z ́ ~ z a ~ m n a q) ~}\end{array}$ & - & $\begin{array}{c}+ \\
(\text { dni... sprawy })\end{array}$ \\
\hline paratekst tłumacza & - & - & + & - & + \\
\hline Wynik:_/10 & 4 & 6 & 9 & 8 & 9 \\
\hline
\end{tabular}




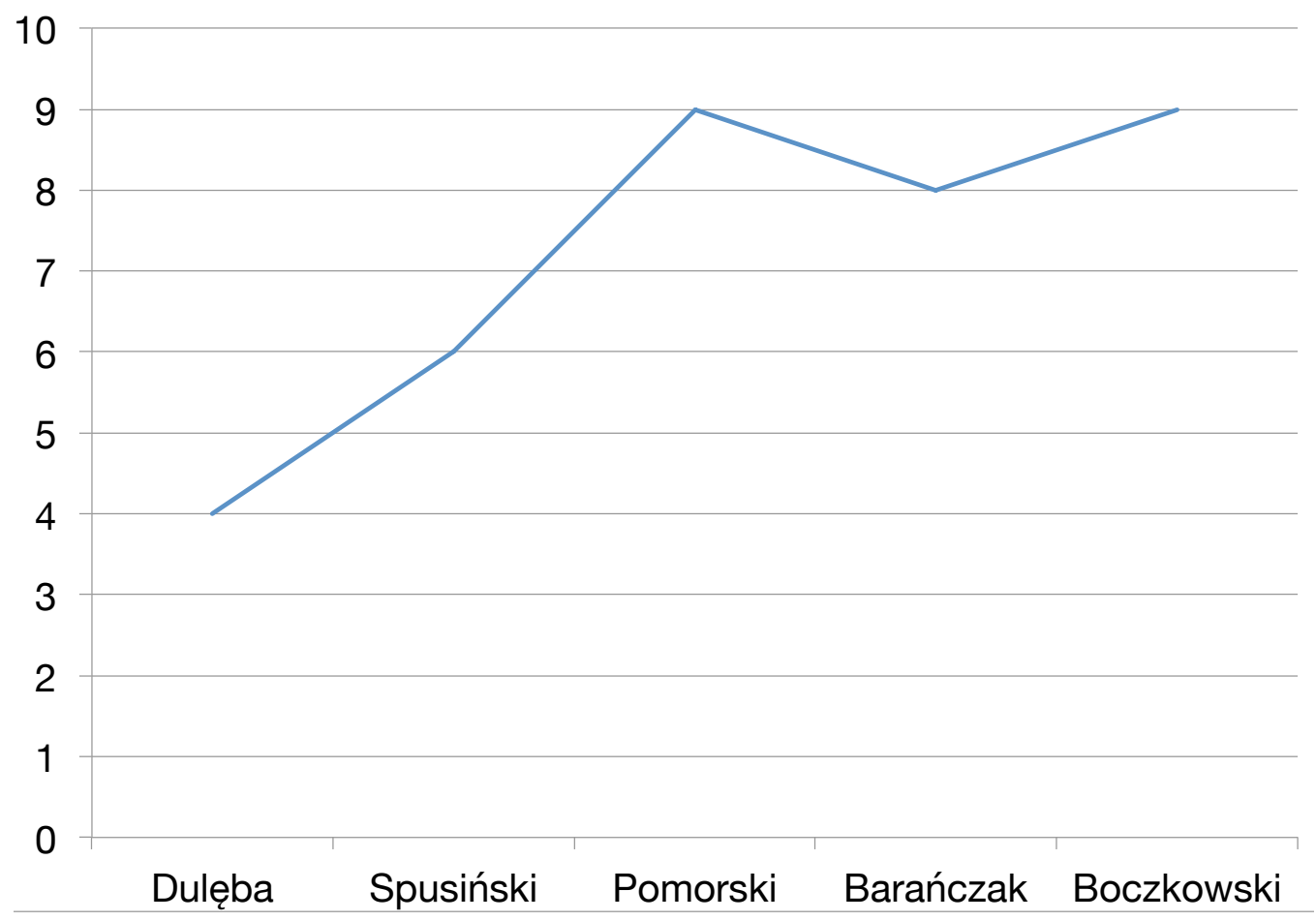

Wykres 4. Intertekstualność w analizowanej serii translatorskiej

\section{Wnioski}

Nałożone na siebie linie wykresów pozwalają zobaczyć jakość przekładów jako zjawisko wieloaspektowe (wykres 5: warianty a i b obrazują płaski i przestrzenny rzut tych samych wyników). Jak widać, wszelka ocena dokonywana na podstawie poprzednich diagramów cząstkowych byłaby wysoce niemiarodajna i nawet wspólny obraz wszystkich czterech krzywych nie jest jednoznaczny. O ogólnie wysokiej jakości przekładu można mówić dopiero wtedy, gdy wszystkie krzywe (lub ich większość) przebiegają dla tego ogniwa serii w górnej części wykresu (por. przebieg dla hipotetycznego tłumaczenia czwartego w wyobrażonej serii idealnej na wykresie 6). 


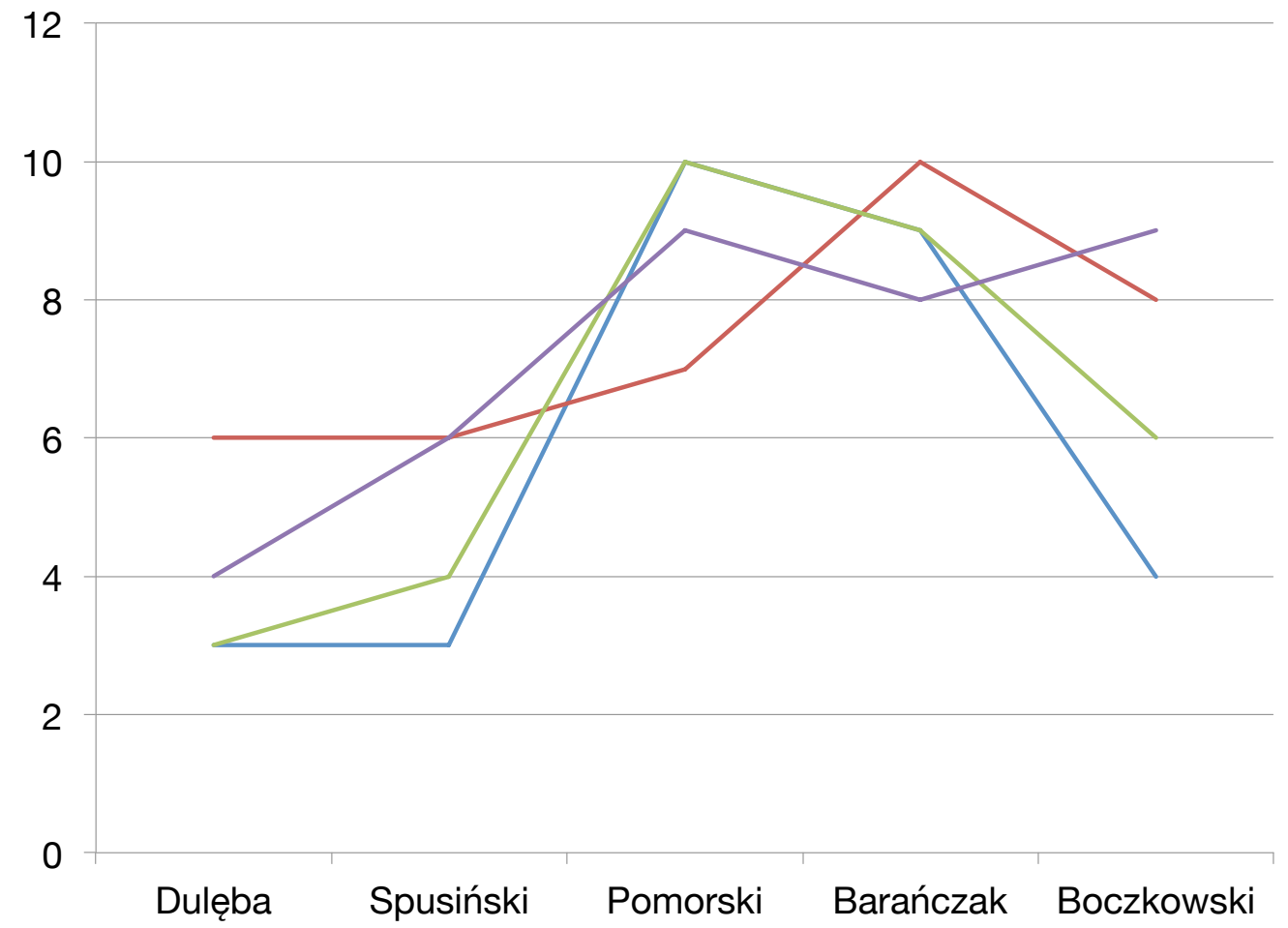

Wykres 5a. Cztery badane aspekty w ujęciu łącznym

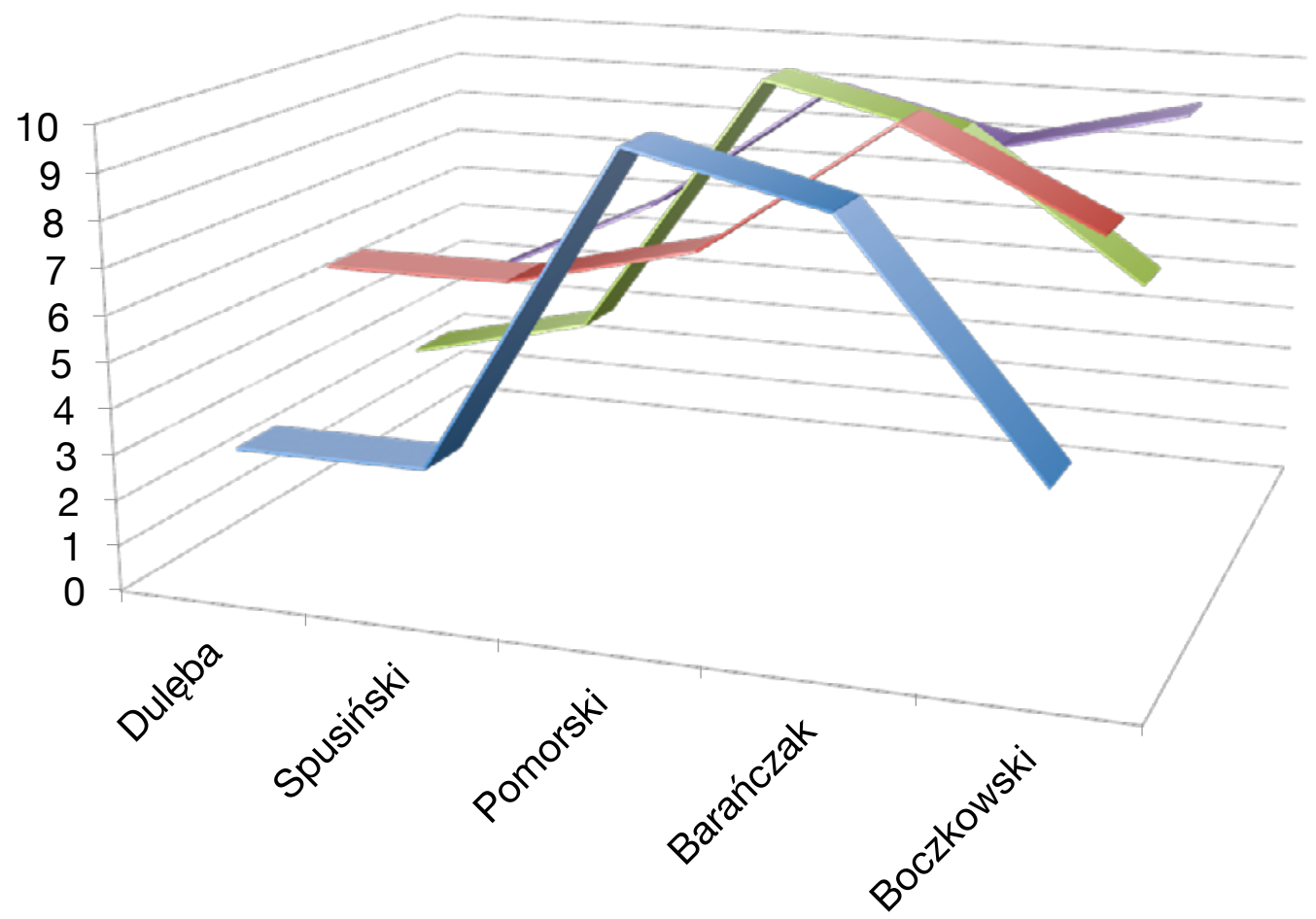

- walory dźwiękowy

- oś tematyczna: niepewność, niezdecydowanie

- warstwa językowa

- intertekstualność

Wykres 5b. Cztery badane aspekty w ujęciu łącznym

walory dźwiękowy

oś tematyczna: niepewność, niezdecydowanie

warstwa językowa

- intertekstualność 


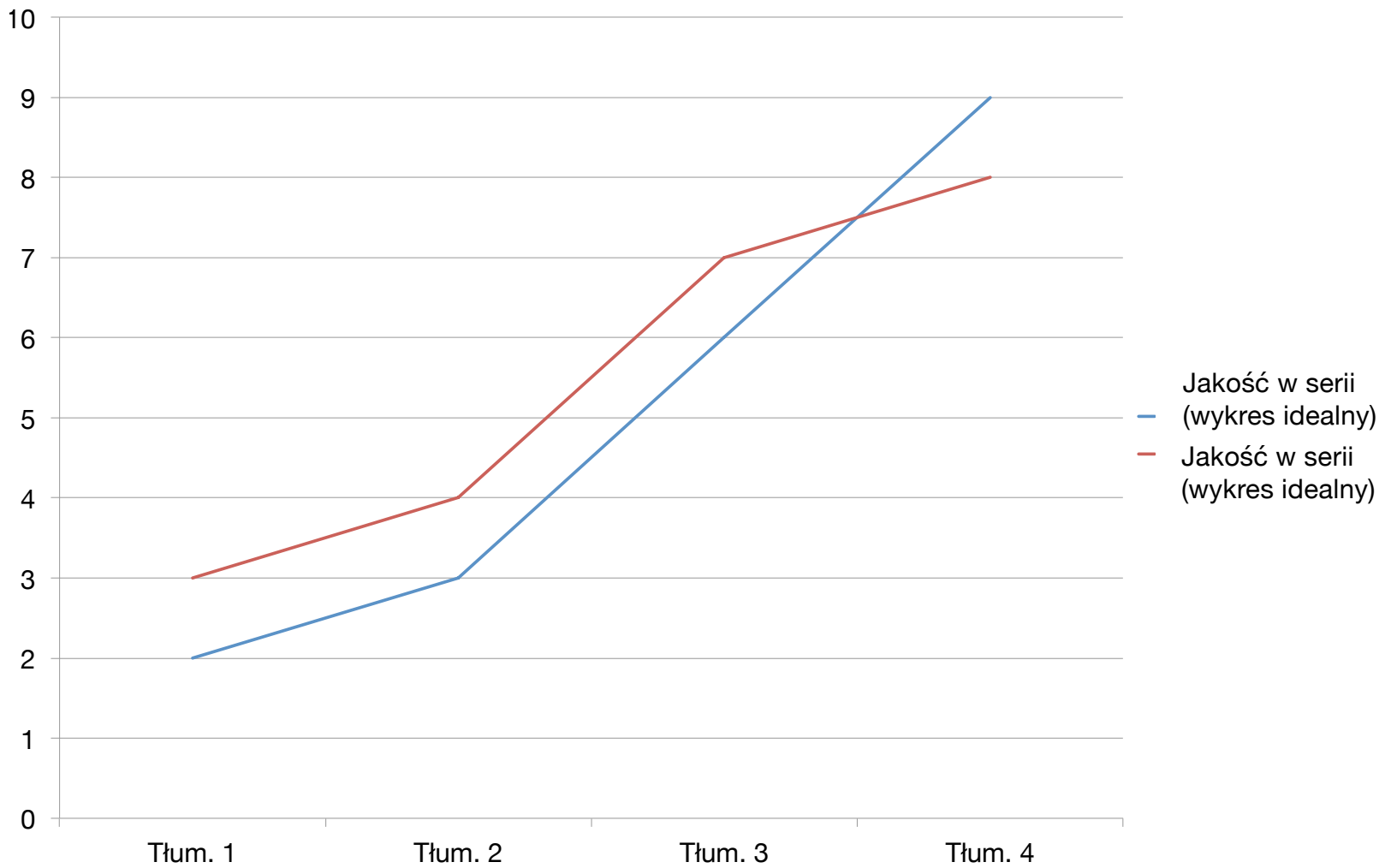

Wykres 6. Jakość w serii hipotetycznej, o idealnym, stałym wzroście

Jakość przekładu przedstawiona jako wiązka aspektów pokazuje, że poszczególne krzywe mają odmienny przebieg. Oznacza to, że w kolejnych retranslacjach jakość może pod jednym względem rosnąć, pod innym zaś maleć - przynajmniej tak dzieje się w przypadku omawianej serii.

Jednocześnie - nasza seria ujmowana całościowo nie wykazuje zdecydowanej progresji jakościowej, choć chyba potwierdza, że tłumaczenia Władysława Dulęby na ogół słusznie były uważane za mozolne raczej niż dobre ${ }^{82}$ i, jako pionierskie, pełniły głównie funkcję informacyjną. Wanda Rulewicz chwaliła przekład Michała Sprusińskiego za dochowanie „wiernoś[ci] oryginałowi w warstwie brzmieniowej" ${ }^{33}$, wszelako w świetle zaprezentowanych tu analiz była to chyba ocena na wyrost i mogła wynikać po części z faktu, iż krytyczka nie zdawała sobie sprawy z niektórych walorów wiersza Eliota, po części zaś z braku bardziej melodyjnych tłumaczeń, z którymi można by było ten wariant wówczas porównać. Polska seria translatorska The Love Song of J. Alfred Prufrock osiąga, jak się wydaje, najwyższą jakość, w wersjach Adama Pomorskiego i Stanisława Barańczaka. Mówiąc ściślej: względnie najwyższą, gdyż w obu wypadkach doskonałość w jakimś zakresie okupiona jest niższym wynikiem w innych badanych obszarach. Przekład Boczkowskiego w dwóch polach ma wyniki dobre, a w dwóch innych przeciętne, zatem - choć powstał najpóźniej

\footnotetext{
${ }^{82}$ Heydel twierdzi, iż gubi się w nich właśnie to, co stanowi o nowatorstwie poetyki Eliota (Obecność T.S. Eliota $w$ literaturze polskiej, s. 151). Na przykładzie Gerontiona badaczka pokazuje, jak tłumacz narzuca zbyt wysoką, quasi-biblijną i archaiczną dykcję w miejscach, gdzie oryginał posługuje się stylem potocznym.

${ }^{83}$ W. Rulewicz, Wstęp, [w:] T.S. Eliot, Wybór poezji, red. K. Boczkowski, W. Rulewicz, s. cxiii-cxiv.
} 
- nie przewyższa pod względem jakości poprzednich tłumaczeń, wbrew temu, czego można by oczekiwać przy prostolinijnym rozumieniu rozwojowego charakteru serii translatorskiej.

Nie wszystkie istotne aspekty oryginału i przekładów zostały w niniejszym studium przebadane i zmierzone. Szczególnie interesująca byłaby analiza tłumaczeń The Love Song pod kątem spójności tekstu - sprawdzenie, czy jego wewnętrznej logiki nie zakłóciły przekładowe omyłki i czy udało się uniknąć wygładzania (racjonalizacji) meandrującego toku myśli podmiotu. Im więcej składników (elementów wiązki) weźmie się pod uwagę, tym większa pewność rzetelnej oceny.

Wykresy same w sobie nie stanowią, oczywiście, metody badawczej, jedynie sposób prezentacji wyników. Myślę jednak, że w przekonujący sposób wskazują potrzebę przeprowadzania analizy o charakterze hierarchicznym i brania pod uwagę różnych komponentów decydujących o jakości. Taka formalizacja pomaga również dostrzec np., że zmiany poziomu jakości w tłumaczeniu warstwy językowej poematu oraz w odtwarzaniu walorów fonoestetycznych dały podobny wykres, tzn. zauważyć można zbieżną tendencję, która zasługuje być może na dokładniejsze zbadanie.

Na koniec warto chyba wrócić do wymienionych na początku artykułu warunków wzrostu jakości w serii translatorskiej, odnosząc je do serii będącej przedmiotem niniejszych rozważań, ze szczególnym uwzględnieniem najnowszego jej ogniwa.

\section{1. Świadomość istnienia poprzednich elementów serii.}

W tym konkretnym przypadku ranga poszczególnych tłumaczy, ich zainteresowanie Eliotem i propagowanie jego dzieł (Sprusiński, Pomorski, Boczkowski) bądź znana skądinąd praktyka translatorska (Barańczak) pozwalają zakładać, iż znali oni przekłady wcześniejsze. Oczywiście przy braku bezpośrednich świadectw ze strony danego tłumacza trudno byłoby ustalić, czy zaglądał on do nich w trakcie pracy nad własną wersją, ale tak czy inaczej można uznać, iż ów wstępny warunek został spełniony. Przynajmniej jeden z tłumaczy, Krzysztof Boczkowski, przyznaje, że zna „poprzednie wersje”.

2. Intencja przewyższenia przekładów istniejących.

Boczkowski przy jednej okazji otwarcie kwestionuje decyzje swoich poprzedników. Twierdzi on, iż wers 88, „After the cups, the marmalade, the tea”, był „błędnie tłumaczony w dotychczasowych przekładach", nie wskazuje jednak, o które wersje mu chodzi ${ }^{84}$. Można by rzec, iż nie ma większego znaczenia, czy słowo cup rozumie się jako filiżankę, czy jako rodzaj alkoholu (choć w danym wersie napój byłby istotnie bardziej logiczny), i czy/że marmalade musi być koniecznie zrobiona z owoców cytrusowych. Jednak, choć Boczkowski, o dziwo, nie polemizuje w podobny sposób w żadnej z kluczowych kwestii, to owa pojedyncza uwaga ujawnia jego intencję jako przynajmniej po części korekcyjną.

3. Znajomość aktualnego stanu badań nad twórczością danego autora lub nad danym dziełem, a także krytyki przekładów dokonanych przez ich poprzedników.

${ }^{84}$ T.S. Eliot, Szepty nieśmiertelności, s. 103. 
Jak zauważyła Jean Ward, choć polscy tłumacze Eliota w większości doskonale orientują się w tym przedmiocie, zdarza im się przeoczyć pewne cechy jego poetyki, które badacze uznają za kluczowe i warte ocalenia ${ }^{85}$. Obserwację tę potwierdza tom Boczkowskiego, w którym widoczna jest niewątpliwa erudycja, a przy tym prezentowany w nim Prufrock to pod względem artystycznym z pewnością nie jest ostatnie słowo.

4. Swoboda wykorzystywania najbardziej fortunnych rozwiązań poprzedników.

Nawet na wczesnym etapie rozwoju serii niektóre powtórzenia wydają się niezbędne i podyktowane przez sam oryginał. Jak sugerowałam w kontekście dwuwiersza o Michale Aniele, pewne niekoniecznie optymalne rozwiązania mogą wynikać z niechęci do powtarzania wariantów użytych wcześniej. Boczkowski niekiedy, owszem, korzysta z wersji poprzedników w sposób bardziej oczywisty, co zasygnalizowałam na dwu przykładach w trzeciej części analizy: były to dobór słowa powtórzony za przekładem drugim i sformułowanie podstawia grzbiet za przekładem trzecim. Nie zawsze takie postępowanie okazuje się fortunne (jak w przypadku czasownika utrwalać).

W sumie wszystkie warunki udało się chyba Boczkowskiemu spełnić, a mimo to linie krzywe w ostatnim segmencie wykresu niekoniecznie się wznoszą. Tym bardziej więc należy zachowywać ostrożność w postrzeganiu serii translatorskiej w kategoriach rozwojowych, a także - przy dodawaniu do niej kolejnych ogniw.

${ }^{85}$ Zob. J. Ward, Autoaluzja i inne cechy poezji T.S. Eliota..., s. 346.

Przełożyły z angielskiego

Marta Kaźmierczak i Ewa Kraskowska 


\title{
SŁOWA KLUCZOWE:
}

\section{STYL}

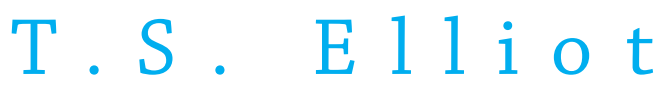

\begin{abstract}
AbStrakT:
Przedmiot artykułu stanowi zagadnienie jakości przekładu w ramach serii translatorskiej. Autorka wychodzi od przypomnienia rozważań teoretycznych na temat serii i od potencjalnie wpisanego w ten koncept oczekiwania wzrastających walorów kolejnych ogniw. Zbadaniu fluktuacji jakości w rzeczywistej serii przekładowej posłużyło pięć polskich tłumaczeń Pieśni miłosnej J. Alfreda Prufrocka T.S. Eliota. Analizie poddano cztery istotne dla poetyki poematu aspekty oryginału i przekładów oraz zestawiono rezultaty w poszczególnych sferach. Celem pracy jest nie tyle krytyka przekładów, co próba wymodelowania zmian jakościowych, jakim podlegały różne aspekty poetyki utworu wraz z przyrastaniem serii.
\end{abstract}




\section{seria translatorska}

\section{intertekstualność}

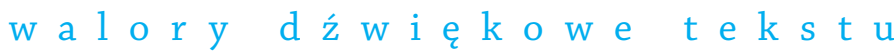

\section{NOTA O AUTORzE:}

Marta Kaźmierczak - dr, rusycystka, anglistka, przekładoznawca, adiunkt w Instytucie Lingwistyki Stosowanej UW. Jej główne zainteresowania badawcze to kulturowe aspekty przekładu, intertekstualność, intersemiotyczność, tłumaczenie poezji. Autorka monografii Przekład w kręgu intertekstualności. Na materiale tłumaczeń poezji Bolesława Leśmiana (Warszawa 2012) i ponad trzydziestu rozpraw dotyczących tłumaczenia i recepcji. 